\title{
The Political Economy of Fiscal Adjustments
}

\section{Citation}

Alesina, Alberto, Roberto Perotti, and José Tavares. 1998. "The Political Economy of Fiscal Adjustments." Brookings Papers on Economic Activity (Spring): 197-266.

\section{Published Version}

http://www.brookings.edu/ /media/Projects/

BPEA/1998\%201/1998a_bpea_alesina_perotti_tavares_obstfeld_eichengreen.PDF

\section{Permanent link}

http://nrs.harvard.edu/urn-3:HUL.InstRepos:12553724

\section{Terms of Use}

This article was downloaded from Harvard University's DASH repository, and is made available under the terms and conditions applicable to Other Posted Material, as set forth at http:// nrs.harvard.edu/urn-3:HUL.InstRepos:dash.current.terms-of-use\#LAA

\section{Share Your Story}

The Harvard community has made this article openly available.

Please share how this access benefits you. Submit a story.

Accessibility 


\author{
ALBERTO ALESINA
}

Harvard University

ROBERTO PEROTTI

Columbia University

JOSÉ T A VARES

Harvard University

\title{
The Political Economy of Fiscal Adjustments
}

FISCAL DISCIPLINE is currently the main macroeconomic problem faced by industrial and developing countries. Following the fiscal profligacy of the 1970s and early 1980s, deficit reduction has dominated the political economy debate during the past few years. The United States, after experiencing mounting deficits in the early and mid-1980s, has recently achieved a balanced budget. In Latin America, several countries show a marked improvement in their budget balances since the "lost decade" of the 1980s, although it remains to be seen how permanent these adjustments are. ${ }^{1}$ In Europe, inflation is stable and low, and most countries joining the European Monetary Union (EMU) have easily satisfied the convergence criterion on inflation, but achieving the fiscal targets has proved a more difficult task. ${ }^{2}$ Deficit reduction policies

We are grateful to our discussants, Barry Eichengreen and Maurice Obstfeld, and to the other participants of the Brookings Panel meeting for helpful and constructive comments. We also thank Olivier Blanchard, Benjamin Friedman, Xavier Gabaix, and participants of seminars at Harvard University, Boston College, and the Istituto per la Programmazone Economica in Rome for useful suggestions. We are grateful to Teng Chamchumrus for excellent research assistance and Silvia Ardagna for help with the data. Alesina and Perotti are grateful to the National Science Foundation for a grant through the National Bureau of Economic Research, and Tavares acknowledges financial support from the Banco de Portugal and the Fundação para a Ciência e Tecnologia in Lisbon.

1. For a discussion of fiscal policy in Latin America, see Gavin and Perotti (1997).

2. For an excellent discussion of the process of European integration and the convergence criteria for EMU, see Obstfeld (1997). 
are almost always associated with politically charged issues, such as the retrenchment of overextended welfare states, the reform of insolvent public pension systems, and the trimming of large and inefficient bureaucracies.

The textbook view, embraced by most policymakers, is that to reduce budget deficits is contractionary, at least in the short run. Since a recession is a major electoral liability, governments hesitate to pursue fiscal adjustments. However, recent research casts doubt on this seemingly unquestionable "stylized fact.", ${ }^{3}$ Is it accurate, then, to say that fiscal adjustments are a political liability?

In this paper we reexamine the research on the economic effects of fiscal adjustments. Not all fiscal consolidations are contractionary: some are and some are not. In particular, we emphasize that the composition of the adjustment matters. We confirm and extend evidence that fiscal corrections relying mostly on spending cuts that are concentrated on government wages and transfers tend to be expansionary, whereas those relying mainly on tax increases are contractionary.

The second and main purpose of the paper is to investigate whether governments that follow tight fiscal policies tend to be replaced in office, or more generally, whether they lose popularity as they cut deficits. The answer to both questions is a loud no. Using data drawn from a sample of nineteen countries in the Organisation for Economic Co-operation and Development (OECD), we find no evidence of a systematic electoral penalty or fall in popularity for governments that follow restrained fiscal policies. If anything, the opposite is the case: when deficits are reduced, governments that follow a "cold turkey" approach and focus on spending cuts may be rewarded at the ballot box. Moreover, cabinets that are willing to cut transfers and the government wage bill - traditionally considered the two most politically charged components of spending - are not punished by the voters.

Specifically, our results on the politics of fiscal adjustments can be summarized as follows. First, a coalition government is much less likely to succeed in consolidating the budget than a single party government. Second, there is no evidence that looser fiscal policy implies longer political tenure. Third, in a period of fiscal adjustment, a government

3. In particular, see Giavazzi and Pagano (1990); Perotti (1997); Alesina and Ardagna (1998). 
that relies on spending cuts may survive longer. Fourth, cuts in the government wage bill and in transfers do not increase the probability that the government will collapse. And fifth, the popularity of a government does not fall in the immediate aftermath of fiscal adjustments.

One can think of two reasons why a cabinet that reduces a budget deficit might not be punished at the ballot box or in opinion polls: either the voters are fiscally prudent themselves and approve of tight fiscal policies, or fiscally prudent governments choose the appropriate moment to implement unpopular policies - when they know that they can "get away" with it. In trying to disentangle these issues, we provide evidence in favor of the first interpretation.

We are not aware of any previous paper that systematically examines the effects of fiscal policy on the popularity and survival of governments in a large sample of OECD countries, but the issue has been addressed in other contexts. In particular, our results are consistent with those of Sam Peltzman, who finds that American voters behave as fiscal conservatives in state gubernatorial elections and do not reward governors who increase spending. ${ }^{4}$ In a study of political business cycles in Latin American countries, Moritz Kraemer provides evidence that voters do not reward cabinets that pursue loose fiscal policies and concludes that " "higher deficits before elections do not seem to contribute to victory at the ballot box." 5

We start by discussing the evidence and the underlying theory for the economic effects of fiscal adjustments. In particular, we focus on issues of composition. We then consider whether various types of government are more or less likely to succeed in fiscal adjustment. We also examine whether governments that engage in fiscal adjustments are less likely to survive and look at the effect of a fiscal adjustment on popularity ratings. Finally, we tackle the question of causality.

\section{The Evidence}

Before analyzing the political economy of fiscal consolidations, we discuss what is known about their economics. In some sense, studying

4. Peltzman (1992). More recently, see Lowry, Alt, and Ferre (1997), who also provide an excellent survey of the earlier literature.

5. $\operatorname{Kraemer}(1997$, p. 3). 
the economics of fiscal consolidations implies studying the effects of fiscal policy in general. Within this very wide topic, we focus on large episodes of fiscal consolidation. We start by pointing out some interesting empirical regularities in the data, which, although in the nature of simple correlations, we find highly suggestive. We then take into account initial conditions and accompanying policies, so as to partial out some concomitant factors. Although the empirical regularities appear to be very robust, their causal interpretation is an open issue. We cannot categorically decide among several contrasting interpretations; nevertheless, we do provide a coherent explanation for these results in the next section.

Empirical work on the effects and sustainability of fiscal adjustments has consistently reached two conclusions. ${ }^{6}$ First, long-lasting adjustments rely mostly (or exclusively) on spending cuts, in particular, in government wages and social security and welfare; by contrast, shortlived adjustments rely mostly on revenue increases. Second, fiscal adjustments are not always associated with reduced growth, or with a deterioration in the macroeconomic environment in general.

We illustrate these results by isolating episodes of fiscal adjustments based on the behavior of the primary budget deficit, identifying which are persistent and which are not, and finally, characterizing the associated macroeconomic developments. ${ }^{7} \mathrm{We}$ also examine the deficit corrected for cyclicality using a method based on the work of Olivier Blanchard, as described in appendix A below. ${ }^{8}$ We consider primary rather than total deficits - that is, we exclude interest payments because we are interested in discretionary changes in fiscal variables.

\section{The Persistence of Fiscal Consolidations}

We define a year of tight fiscal policy as a year when the ratio of the primary deficit to GDP falls (or the ratio of the surplus to GDP increases) by at least 1.5 percentage points. Such a fiscal adjustment can either be successful or unsuccessful: we define success in relation to

6. See Giavazzi and Pagano (1990, 1996); Alesina and Perotti (1995, 1996, 1997a); Alesina and Ardagna (1998); McDermott and Wescott (1996); International Monetary Fund (1996); Perotti (1997).

7. This section revisits and updates evidence originally presented in Alesina and Perotti $(1995,1997 a)$.

8. Blanchard (1990b). 
Table 1. Composition of Successful and Unsuccessful Adjustments, No Cyclical Correction ${ }^{\mathrm{a}}$

Percentage points of GDP

\begin{tabular}{lcccc}
\hline Sample & $\begin{array}{c}\text { Number of } \\
\text { observations }\end{array}$ & CHDEF & CHEXP & CHREV \\
\hline Successful adjustments $^{\mathrm{b}}$ & 23 & -2.61 & -1.73 & 0.88 \\
& & $(0.21)$ & $(0.28)$ & $(0.26)$ \\
Unsuccessful adjustments $^{\mathrm{b}}$ & 49 & -2.16 & -0.58 & 1.58 \\
& & $(0.11)$ & $(0.19)$ & $(0.15)$ \\
\hline
\end{tabular}

Source: For sources of all data and explanations of all variables, see appendix A

a. Table gives means and standard deviations (in parentheses) from a panel that is described in appendix A. The panel spans 1965-95, but in this table 1993-95 are excluded, since the success of an adjustment cannot be determined until three years after it occurred. Deficit is not cyclically corrected.

b. In this table, a country-year observation counts as an adjustment year if the ratio of the primary deficit to GDP is reduced by at least 1.5 percentage points $(C H D E F \leq-1.5)$. An adjustment is successful if it meets one of the following two criteria: either in the three years following the adjustment year, the deficit-to-GDP ratio is on average at least 2 percentage points below its level in the adjustment year; or three years after the adjustment, the debt-to-GDP ratio is at least 5 percentage points below its level in the adjustment year. In all other cases, an adjustment is deemed unsuccessful.

the persistence of the deficit reduction. Thus a year of tight fiscal policy is successful if one of the following two conditions applies: either, in the three years after the tight year, the ratio of the primary deficit to GDP is on average at least 2 percentage points below its level in the tight year; or, three years after the year of the adjustment, the debt-toGDP ratio is at least 5 percentage points below its level in the adjustment year.

For the cyclically corrected measure, these thresholds are applied to the corrected deficit. The resulting set of years of tight fiscal policy is very similar to the set for uncorrected deficits. While there is a certain amount of discretion in the choice of criteria, sensitivity analysis confirms that the results do not change qualitatively with different criteria.

In the remainder of this section we use our data set of nineteen OECD countries over the period 1960-95 to investigate the nature and effects of fiscal adjustments. ${ }^{9}$ Table 1 presents summary statistics for successful and unsuccessful adjustments. It shows that in successful adjustments two-thirds of the deficit reduction comes from spending cuts, while in unsuccessful adjustments only about one-quarter of the adjustment is on the spending side. The standard deviations show that the

9. Our sample includes the following countries: Australia, Austria, Belgium, Canada, Denmark, Finland, France, Germany, Greece, Ireland, Italy, Japan, the Netherlands, Norway, Portugal, Spain, Sweden, the United Kingdom, and the United States; see appendix A for further details. 
Table 2. Composition of Successful and Unsuccessful Adjustments, Deficit Cyclically Corrected $^{\mathrm{a}}$

Percentage points of GDP

\begin{tabular}{lcccc}
\hline & $\begin{array}{c}\text { Number of } \\
\text { Sample }\end{array}$ & & & \\
\hline Successful adjustments $^{\mathrm{b}}$ & 19 & -2.96 & -1.58 & 1.37 \\
& & $(0.34)$ & $(0.33)$ & $(0.47)$ \\
Unsuccessful adjustments $^{\mathrm{b}}$ & 50 & -2.47 & -0.62 & 1.86 \\
& & $(0.15)$ & $(0.26)$ & $(0.20)$ \\
\hline
\end{tabular}

Source: For sources of all data and explanations of all variables, see appendix A.

a. Table gives means and standard deviations (in parentheses) from a panel that is described in appendix A. The panel spans 1965-95, but in this table 1993-95 are excluded, since the success of an adjustment cannot be determined until three years after it occurred. Deficit is cyclically corrected.

b. For definitions of an adjustment year and the success of an adjustment, see table 1, note b. In the present table, adjustment and success criteria are based on the cyclically corrected deficit.

differences are statistically significant. In regard to size, the deficit cut is only slightly larger in successful than in unsuccessful adjustments. This indicates that, independent of the size of the adjustment, its composition matters. The qualitative nature of the results does not change when we use the cyclically corrected measure of deficits, as reported in table 2 .

Table 3 shows that there are critical differences in the composition of spending cuts between successful and unsuccessful adjustments. In successful adjustments more than half of the spending cut derives from cuts in transfers and government wages, but in unsuccessful adjustments these two components are virtually untouched. ${ }^{10}$ Alesina and Perotti show elsewhere that in successful adjustments, the cuts in the government wage bill derive from a combination of reductions in wage rates and in the level, or at least the growth rate, of public employment. ${ }^{11}$ In some cases, public employment was very greatly reduced. ${ }^{12}$ Successful adjustments also cut nonwage government consumption and subsidies more than in unsuccessful adjustments. In sum, in unsuccessful adjustments the burden of spending cuts primarily falls on public investment.

On the revenue side, Alesina and Perotti show in the same study that

10. The average changes in transfers and the wage bill are significantly different from zero in successful adjustments, but are not in unsuccessful adjustments.

11. Alesina and Perotti (1997a).

12. In Ireland, for example, government employment fell by about 10 percent between 1986 and 1989 , from about 300,000 to 270,000 employees. 


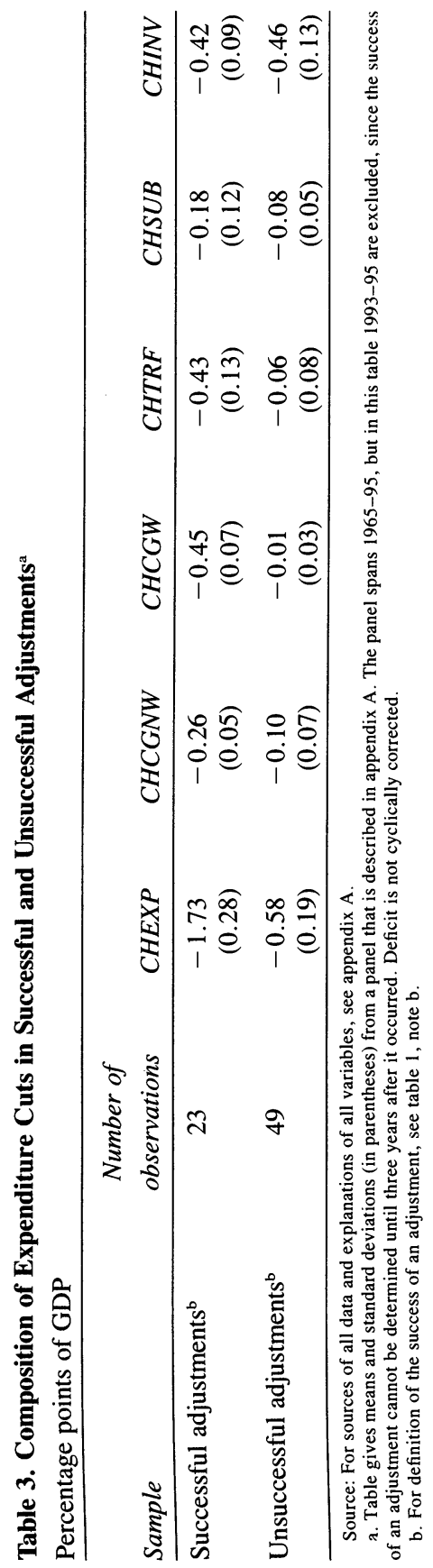


the most successful adjustments do not increase taxes on labor (that is, household income taxes and social security taxes), but instead rely on indirect taxes and taxes on business to increase revenue. By contrast, unsuccessful adjustments rely heavily on increases in taxes on labor.

\section{Fiscal Consolidations and the Macroeconomy}

Table 4 presents statistics on macroeconomic conditions before, during, and after successful and unsuccessful adjustments. Several interesting observations emerge. First, the rate of growth relative to the G7 countries increases during a successful adjustment and decreases during an unsuccessful one. Unemployment relative to the G7 average falls after a successful adjustment and increases after an unsuccessful adjustment, although these changes are quite small. Moreover, the rate of growth relative to the $\mathrm{G} 7$ immediately before a successful adjustment is actually lower than that before an unsuccessful one, suggesting that success is not due to the fact that the economy was growing rapidly before the adjustment.

Second, during and immediately after a successful adjustment, a country experiences an investment "boom," which is much larger than in an unsuccessful adjustment. In the two years following a successful adjustment, the rate of growth of investment is 8.58 percent, compared with 2.35 percent after an unsuccessful adjustment. Consumption also increases significantly during a successful adjustment, although the difference in the pattern of consumption between the two cases is less striking than for investment.

Third, both successful and unsuccessful adjustments are accompanied by a currency depreciation. ${ }^{13}$ The depreciation is slightly larger before a successful adjustment.

Fourth-and perhaps most interesting - the two types of adjustment exhibit striking differences of labor market behavior. Unit labor costs fall before and during successful adjustments, whereas they increase during unsuccessful adjustments. Two indicators suggest that profits increase during successful adjustments and decline in unsuccessful ones. The first is the behavior of the ratio of the manufactured exports

13. In table 4 , a minus sign corresponds to a depreciation. 
Table 4. Macroeconomic Indicators Before, During, and After Adjustments ${ }^{\mathrm{a}}$

Percentage points

\begin{tabular}{|c|c|c|c|c|c|c|}
\hline \multirow[b]{2}{*}{ Indicator } & \multicolumn{3}{|c|}{ Successful adjustments ${ }^{\mathrm{b}}$} & \multicolumn{3}{|c|}{ Unsuccessful adjustments $^{\mathrm{b}}$} \\
\hline & Before $^{\mathrm{c}}$ & During & After ${ }^{\mathrm{c}}$ & Before ${ }^{\mathrm{c}}$ & During & After ${ }^{\mathrm{c}}$ \\
\hline$\Delta G D P g 7$ & $\begin{array}{c}-0.30 \\
(0.26)\end{array}$ & $\begin{array}{c}0.10 \\
(0.42)\end{array}$ & $\begin{array}{c}0.19 \\
(0.38)\end{array}$ & $\begin{array}{c}0.13 \\
(0.22)\end{array}$ & $\begin{array}{r}-0.30 \\
(0.34)\end{array}$ & $\begin{array}{r}-0.20 \\
(0.30)\end{array}$ \\
\hline UNRg7 & $\begin{array}{c}1.83 \\
(1.08)\end{array}$ & $\begin{array}{c}1.87 \\
(1.07)\end{array}$ & $\begin{array}{c}1.46 \\
(1.02)\end{array}$ & $\begin{array}{c}-0.14 \\
(0.47)\end{array}$ & $\begin{array}{c}0.01 \\
(0.48)\end{array}$ & $\begin{array}{c}0.30 \\
(0.50)\end{array}$ \\
\hline$\Delta I N V$ & $\begin{array}{c}1.82 \\
(1.42)\end{array}$ & $\begin{array}{c}6.85 \\
(1.18)\end{array}$ & $\begin{array}{c}8.58 \\
(1.13)\end{array}$ & $\begin{array}{c}2.16 \\
(1.05)\end{array}$ & $\begin{array}{c}6.49 \\
(1.58)\end{array}$ & $\begin{array}{c}2.35 \\
(1.19)\end{array}$ \\
\hline$\triangle C O N S$ & $\begin{array}{c}1.99 \\
(0.37)\end{array}$ & $\begin{array}{c}3.08 \\
(0.50)\end{array}$ & $\begin{array}{c}3.32 \\
(0.40)\end{array}$ & $\begin{array}{c}3.02 \\
(0.30)\end{array}$ & $\begin{array}{c}3.54 \\
(0.33)\end{array}$ & $\begin{array}{c}3.25 \\
(0.36)\end{array}$ \\
\hline NINTRTg7 & $\begin{array}{c}2.27 \\
(0.45)\end{array}$ & $\begin{array}{c}1.86 \\
(0.34)\end{array}$ & $\begin{array}{c}2.06 \\
(0.47)\end{array}$ & $\begin{array}{c}2.31 \\
(0.61)\end{array}$ & $\begin{array}{c}2.97 \\
(0.72)\end{array}$ & $\begin{array}{c}3.30 \\
(0.72)\end{array}$ \\
\hline RINTRTg7 & $\begin{array}{c}0.28 \\
(0.61)\end{array}$ & $\begin{array}{c}-1.01 \\
(0.74)\end{array}$ & $\begin{array}{c}0.40 \\
(0.40)\end{array}$ & $\begin{array}{c}-1.44 \\
(0.42)\end{array}$ & $\begin{array}{c}-1.78 \\
(0.49)\end{array}$ & $\begin{array}{r}-0.16 \\
(0.39)\end{array}$ \\
\hline$\triangle E F X C H R T$ & $\begin{array}{r}-3.89 \\
(1.10)\end{array}$ & $\begin{array}{c}-2.15 \\
(1.32)\end{array}$ & $\begin{array}{c}0.29 \\
(1.05)\end{array}$ & $\begin{array}{r}-2.90 \\
(0.93)\end{array}$ & $\begin{array}{r}-2.66 \\
(0.96)\end{array}$ & $\begin{array}{r}-1.89 \\
(0.89)\end{array}$ \\
\hline$T B$ & $\begin{array}{r}-0.50 \\
(0.96)\end{array}$ & $\begin{array}{c}0.56 \\
(1.09)\end{array}$ & $\begin{array}{c}0.60 \\
(1.06)\end{array}$ & $\begin{array}{c}-2.38 \\
(1.06)\end{array}$ & $\begin{array}{r}-1.97 \\
(0.93)\end{array}$ & $\begin{array}{r}-1.83 \\
(0.87)\end{array}$ \\
\hline$\Delta U L C$ & $\begin{array}{r}-4.48 \\
(1.35)\end{array}$ & $\begin{array}{r}-1.06 \\
(1.64)\end{array}$ & $\begin{array}{c}3.25 \\
(1.40)\end{array}$ & $\begin{array}{c}-0.50 \\
(0.76)\end{array}$ & $\begin{array}{c}1.27 \\
(0.91)\end{array}$ & $\begin{array}{c}0.50 \\
(0.90)\end{array}$ \\
\hline$\triangle V A U L C$ & $\begin{array}{c}2.75 \\
(1.27)\end{array}$ & $\begin{array}{c}4.14 \\
(1.44)\end{array}$ & $\begin{array}{r}-1.46 \\
(1.09)\end{array}$ & $\begin{array}{c}0.85 \\
(0.74)\end{array}$ & $\begin{array}{r}-0.21 \\
(0.98)\end{array}$ & $\begin{array}{r}-1.47 \\
(0.84)\end{array}$ \\
\hline$P S H$ & $\begin{array}{l}30.80 \\
(0.88)\end{array}$ & $\begin{array}{c}31.92 \\
(0.89)\end{array}$ & $\begin{array}{c}32.09 \\
(0.88)\end{array}$ & $\begin{array}{c}32.64 \\
(1.03)\end{array}$ & $\begin{array}{c}32.35 \\
(1.00)\end{array}$ & $\begin{array}{c}32.80 \\
(0.95)\end{array}$ \\
\hline
\end{tabular}

Source: For sources of all data and explanations of all variables, see appendix $\mathrm{A}$

a. Table gives GDP-weighted means and standard deviations (in parentheses) from a panel that is described in appendix A. The panel spans 1965-95, but in this table 1993-95 are excluded, since the success of an adjustment cannot be determined until three years after it occurred. Deficit is not cyclically corrected.

b. For definition of the success of an adjustment, see table 1 , note $b$.

c. Period before a year $t$ adjustment comprises years $t-2$ and $t-1$; period after comprises $t+1$ and $t+2$.

deflator to unit labor costs. ${ }^{14}$ The second is the profit share, which also increases during successful adjustments but does not in unsuccessful ones. The opposite is true for the wage share (not shown). The trade

14. We use the manufactured exports deflator because we are interested in the effect of the changes in export profitability - that is, to capture the "competitiveness channel" discussed in Alesina and Perotti (1997b). We in fact obtain a very similar pattern when we use the manufacturing sector deflator. 
balance improves more during successful adjustments than it does in unsuccessful ones, possibly as a consequence of the different behavior of unit labor costs.

The broad picture described is quite robust to several sensitivity checks, and it remains largely the same when we use a cyclically adjusted measure of the change in deficit to identify periods of tight fiscal policy and successful adjustments. These results are also consistent with those of Alesina and Perotti, using a slightly smaller sample and different definitions of adjustment and success. ${ }^{15}$ Moreover, an analysis of many case studies of adjustment by Alesina and Silvia Ardagna points exactly to the same conclusions. ${ }^{16}$

To summarize, table 4 yields two key regularities. First, the macroeconomic environment does not deteriorate during successful adjustments, and the economy performs better than during unsuccessful adjustments. And second, the behavior of labor market and income distribution variables displays a marked asymmetry across the two types of fiscal consolidation.

Finally, a word on monetary policy. A fiscal adjustment should be less contractionary if it is accompanied by loose monetary policy. An exhaustive analysis of the monetary stance of nineteen OECD countries over the past thirty-five years is beyond the scope of this paper. However, a few simple observations suggest that monetary policy is not the whole story behind our results. If it were, one should not observe the strong correlation between the composition of an adjustment and the likelihood of success. Moreover, many of the fiscal adjustments occurred in countries whose monetary policies were "locked in" by the process of convergence toward EMU. In some cases, but not all, large adjustments were accompanied by a devaluation. However, Alesina and Ardagna show that such nominal devaluations were effective and improved the economic outlook only when accompanied by explicit wage agreements with the unions. More generally, they argue that nominal devaluations cannot be the main explanation for expansionary fiscal adjustments. Supply-side policies, such as wage agreements and income policies, accompanied by non-tax-based adjustments are critical.

15. Alesina and Perotti (1997a). Their sample ends in 1993.

16. Alesina and Ardagna (1998) 


\section{The Theory}

One possible interpretation of the evidence presented above is that there is a relationship between the composition of the adjustment, on one side, and both its persistence and its macroeconomic consequences, on the other. Is there a coherent theory for this relationship? The conventional wisdom, at least among governments and international organizations, is that fiscal consolidations are always recessionary; it is the textbook Keynesian argument. Conventional wisdom usually has some justification, and it is often unwise to charge at it as did Don Quixote against windmills. We do not deny that fiscal consolidations are often recessionary, but the evidence reviewed above clearly suggests that this is not always the case. Under what conditions might a consolidation be expansionary? In this section we survey some possible-not mutually exclusive-answers to the two questions raised here.

\section{Wealth Effects and Expectations}

The observation that a cut in government consumption increases private consumption would not be surprising in a neoclassical model. A permanent cut in government consumption, if perceived as such, creates a positive wealth effect, because the accompanying reduction in future tax liabilities increases the wealth of the private sector. According to this model, a fiscal consolidation achieved by a permanent reduction in government spending always increases private consumption. For the present purpose, one needs a model in which a reduction in government consumption is expansionary only under certain conditions relevant to fiscal consolidations, and not under "normal" circumstances.

Table 5 presents the average level of debt at the beginning of the adjustment year and the average change in debt over the three years preceding the adjustment for our full sample, and for the subsamples of successful and unsuccessful adjustments. The table shows that the greater the deterioration of the fiscal situation, the greater is the likelihood that the adjustment will succeed. In particular, the cumulated change in the debt in the three years before a successful adjustment is much larger than that before an unsuccessful adjustment. Also, the adjustments that succeed tend to be undertaken when public debt as 
Table 5. Average Debt at Start of Successful and Unsuccessful Adjustments ${ }^{\mathrm{a}}$

Percentage points of GDP

\begin{tabular}{lcc}
\hline Sample & DEBT & CHDEBT \\
\hline All observations & 47.33 & 3.38 \\
& $(1.09)$ & $(0.40)$ \\
Successful adjusments $^{\mathrm{b}}$ & 68.11 & 13.20 \\
& $(5.88)$ & $(2.54)$ \\
Unsuccessful adjustments $^{\mathrm{b}}$ & 44.34 & 5.10 \\
& $(3.57)$ & $(1.24)$ \\
\hline
\end{tabular}

Source: For sources of all data and explanations of all variables, see appendix A.

a. Table gives means and standard deviations (in parentheses) from a panel that is described in appendix A. The panel spans 1965-95, but in this table 1993-95 are excluded, since the success of an adjustment cannot be determined until three years after it occurred. Deficit is not cyclically corrected.

b. For definition of the success of an adjustment, see table 1 , note b.

share of GDP is relatively high. In fact, as discussed below, recent theoretical work emphasizes that "fiscal stress"' is a potentially important determinant of the effect of fiscal policy.

Suppose that there are real rigidities in the labor market. An increase in government consumption has two effects: it increases employment, and therefore income and consumption, but it also reduces private sector wealth, by increasing the present-discounted value of taxation. If there are credit-constrained individuals, the first effect may well prevail. By contrast, if the distortionary costs of taxation are convex, as is generally assumed, the second effect becomes stronger as the initial level of taxation rises. Hence when the initial level of taxation (in terms of present discounted value) is high - that is, when the initial level of debt is high - the second effect might prevail. This simple model thus offers an explanation for a positive, Keynesian correlation between government consumption shocks and changes in private consumption in normal times, and for a negative, non-Keynesian correlation in times of fiscal stress, as characterized by high initial levels of debt.

In theory, even a tax increase could have expansionary effects under this model. As with government consumption, an increase in taxation has two opposite effects on consumption. It reduces the disposable income, and therefore the consumption, of credit-constrained individuals; but holding government expenditure constant, an increase in taxation today must imply a fall in taxation tomorrow. ${ }^{17}$ If the initial 
expected path of taxation is upward sloping, this will reduce overall distortions by flattening the path of taxation. ${ }^{18}$ At high levels of debt, the initial tax distortions are high; therefore the gain from smoothing taxation is great and the second effect prevails. At low levels of debt, the opposite occurs. Hence one obtains a Keynesian, negative correlation between taxation and changes in private consumption in normal times, and a positive correlation in times of fiscal stress.

Perotti presents evidence elsewhere on the relative importance of Keynesian and non-Keynesian effects of taxation and government consumption. ${ }^{19}$ When he regresses change in private consumption on unexpected changes in government consumption and in taxation, holding constant change in disposable income, the coefficient of government consumption surprises is positive and significant in normal times but negative and significant in periods of fiscal stress, defined as those in which the debt-to-GDP ratio is high and rapidly increasing. ${ }^{20}$ There is much less evidence of significant asymmetry in the effects of taxation. These results are therefore consistent with the evidence presented above, that better macroeconomic developments are associated with successful fiscal consolidations, which reduce government consumption, rather than with unsuccessful consolidations, which increase taxes.

\section{Credibility Effects}

High-debt countries pay interest risk premiums. ${ }^{21}$ Therefore a decisive change in fiscal policy may have large effects on interest rates, because of a "discrete" reduction in default risk and inflation risk. ${ }^{22}$ An important factor in the size of such credibility effects is the presence

described here by Sutherland (1997) and Perotti (1997). Bertola and Drazen (1993) develop a related model, which does not, however, derive a clear-cut empirical implication for the effect of a high level of public debt on the adjustment.

18. Many models of the political economy of fiscal policy would predict an upwardsloping path for taxation; see, for example, Tabellini and Alesina (1990).

19. Perotti (1997).

20. Unexpected changes in government consumption and taxation are estimated as the residuals of a vector autoregression.

21. See Alesina and others (1992) for empirical evidence on default risk in OECD countries.

22. For models with this result, see Calvo (1988); Miller, Skidelsky, and Weller (1990); Alesina, Prati, and Tabellini (1990). 
of multiple equilibria. In the "bad" equilibrium, the budget deficit is high, the risk premium is high, and the large interest burden makes fiscal balance more difficult to achieve and default more likely - so that the high risk premium is rational. In the "good" equilibrium, a low risk premium means that the interest burden is lower and facilitates balancing the budget - so that the low risk premium is rational. Thus a decisive deficit reduction policy can bring about a switch from a suboptimal equilibrium with a high risk premium and a high probability of default to an equilibrium with less risk and lower interest rates. The presence of multiple equilibria implies that even a relatively small fiscal adjustment may have large effects on interest rates. This credibility effect may stimulate all those components of private demand that are very sensitive to interest rates, especially investment.

The initial level of debt may still be important in this context. In fact, the risk premium is likely to be a nonlinear function of debt: nonexistent for low or moderate levels of debt but present with high debt-to-GDP ratios. ${ }^{23}$ Furthermore, a given decrease in the risk premium reduces total deficits more, the larger is the initial level of debt.

\section{Labor Markets}

The evidence presented above points to the importance of labor markets. We identify two empirical regularities in this respect. On one hand, successful consolidations reduce government expenditure on wages and refrain from increasing labor taxes, whereas unsuccessful consolidations do the opposite. On the other hand, unit labor costs and the wage share fall immediately before and during successful consolidations, but do not during unsuccessful consolidations.

These patterns can be rationalized in terms of labor market dynamics and institutions. The economies in our sample are unionized to different degrees. In unionized labor markets, the aggregate labor supply may be quite elastic, even though the individual labor supply is widely regarded to be inelastic. When government wage consumption falls, the bargaining power of unions falls and labor costs decline. By contrast, an increase in labor taxation shifts the aggregate supply of labor, because it reduces the aftertax income of employed union members. The unions will demand higher real wages to compensate for the in-

23. Alesina and others (1992) present evidence of this nonlinearity. 
crease in taxes. Hence the widely different behavior of unit labor costs and the wage share between successful and unsuccessful consolidations can be plausibly explained by differences in the composition of the adjustments.

Alesina and Perotti show elsewhere that the effect of taxes on unit labor costs relative to a country's trading partners is empirically important. ${ }^{24}$ They divide a sample including almost all the OECD countries into three groups, characterized by high, low, or intermediate levels of labor union centralization. In countries with low centralization, the labor market is relatively competitive. In this case, the standard neoclassical labor supply effects hold. In countries with high degrees of centralization, the unions are so large and all-encompassing that they can fully internalize a fiscal adjustment by the government. This implies that the unions may not try to recover the value of a tax hike by raising wages, because they internalize the government's budget constraint. In countries with an intermediate level of centralization, labor unions are strong enough to shift on to the pretax wage most of the increase in labor taxation, but cannot fully internalize the fiscal adjustment and coordinate a wage moderation policy to facilitate the fiscal adjustment. Alesina and Perotti estimate that in this group of countries, increasing the income tax by 1 percent of GDP may cause an increase in relative unit labor costs of up to 2 percent. This effect is smaller both in countries with very high levels of union centralization, such as those in Scandinavia, and in countries with low levels of unionization, such as the United States and Canada.

Alesina and Ardagna examine a selection of the fiscal adjustments in our sample and show that wage moderation in exchange for low tax increases, or explicit incomes policies, is an important aspect of successful fiscal consolidations. ${ }^{25}$ In some cases, such wage moderation has resulted from "consensus" between government and the trade unions; in others, the government has curtailed the unions' power.

In fact, it may be that the main channels through which fiscal policy affects the economy in OECD countries are the cost side of firms and relative unit labor costs. This point is typically overlooked in research based on the assumption of perfectly competitive labor markets-a

24. Alesina and Perotti (1997b).

25. Alesina and Ardagna (1998). 
highly implausible assumption for most European countries. Also, as we argue below, from a political point of view, union behavior is critical in determining the success of fiscal adjustments.

Fiscal policy can influence labor supply in a representative agent, perfectly competitive, neoclassical model. But the direction of the effects is often contrary to that indicated by the empirical regularities. A cut in unproductive government consumption, for example, increases the wealth of individuals, and reduces their labor supply if leisure is a normal good. As a consequence, unit labor costs increase and Tobin's investment $q$ falls, which is exactly the opposite of what the empirical evidence on successful consolidations would suggest. ${ }^{26}$

Similarly, the pure neoclassical model is not a promising starting point for an analysis of the effects of taxation in large fiscal consolidations. On one hand, a tax increase reduces wealth and leisure, thereby increasing labor supply. On the other hand, by the substitution effect, labor supply decreases. But in general, the empirical evidence suggests that these neoclassical labor supply effects are quite small. ${ }^{27}$

\section{Political Effects of Composition}

Cuts in different categories of spending may have different effects on the permanence of a fiscal adjustment, as well as on the political survival of governments, for at least three reasons.

EXPECTATION EFFECTS. Different types of cut may inherently be more or less permanent. For instance, postponing the maintenance of public capital may be only a short-term strategy. By contrast, changes in eligibility criteria and benefit reductions for social security and welfare programs have long-lasting effects. Since welfare cuts are-and are perceived to be-more permanent, they may have strong positive wealth and expectation effects, because they signal permanent reductions in the level of taxes.

From a political standpoint, however, cuts in welfare spending may be particularly unpopular (especially in Europe), whereas cuts in public investment are less visible and costly in the short run, although they come at a higher long-run cost in terms of the productivity of infrastruc-

26. Baxter and King (1993) illustrate the effects of tax and spending policies on labor supply and output in a real business-cycle model.

27. See Pencavel (1986). 
ture. If politicians care more about the short run than the long, they will be biased in favor of investment cuts. Kenneth Rogoff presents a model in which, because of lags in information, even rational voters reward incumbent governments for choosing to cut investment rather than current spending. ${ }^{28}$ Moreover, welfare cuts might imply an increase in post-tax income inequality, which could be an political liability.

POLITICAL CREDIBILITY. Since welfare cuts may be a particularly sensitive issue, governments willing to cut spending on welfare and wages signal that they are really serious about the fiscal adjustment and accept the political risk associated with it. This type of fiscal adjustment thus enjoys increased credibility and may have a stronger effect on interest rates.

Tavares shows that this effect is particularly strong for left-wing governments. Given the preferences of their constituency, it is more costly for left-wing governments to cut public spending. If they actually do so, they signal strong commitment to the fiscal adjustment and build credibility. ${ }^{29}$

LABOR MARKET EFFECTS. Cuts in government wages and employment will have a different effect on labor supply than will cuts in nonwage government consumption. A fall in government employment shifts the aggregate demand facing the union, implying a reduction of unit labor costs. The political costs of cutting government wages or employment may be quite high, though - not so much at the ballot box, but because such policies go against the interests of entrenched bureaucracies.

\section{Summary}

Fiscal adjustments that rely on cuts in government transfers and wages and are implemented in periods of fiscal stress are long lasting and are not contractionary. On the demand side, the expansionary aspect of such fiscal adjustments works through an expectation effect, which is stronger the worse are initial fiscal conditions. On the supply side, the interaction of certain types of adjustment - those without tax increases but with cuts in government employment and wages-lead to

28. Rogoff (1990).

29. Tavares (1998). This is an example of the "why it takes a Nixon to go to China" argument developed formally in Cukierman and Tommasi (1998). 
wage moderation, reduced relative unit labor costs, and increases in profitability, business investment, and production.

\section{Type of Cabinet and Fiscal Adjustments}

In this section we summarize the relationship between cabinets with various party structures and ideological complexions and fiscal policies. In particular, we look at which types of cabinet are more likely to follow deficit reduction policies, and how persistent their policies are likely to be.

\section{Data}

We use the sample of nineteen OECD countries over the period 1960-95 described above. The main variable of interest is the change in the primary deficit. Interest payments are excluded, since the purpose of the exercise is to study the effects of discretionary fiscal policy, and interest rates are not under the direct control of governments, particularly in small open economies. We measure the deficit as a share of GDP.

A crucial issue that arises here is whether to use a cyclically adjusted measure of the primary deficit or the uncorrected measure. There are valid arguments for either method. On the one hand, in favor of using the adjusted measure, voters may try to distinguish cyclical effects from purposeful changes in spending and taxation. For instance, an increase in the deficit due to a surge in unemployment and the associated rise in the volume of unemployment compensation payments may not be regarded in the same way as a deficit increase due to additional discretionary spending. Conversely, a deficit reduction due to a high growth rate may not be perceived in the same way as a deficit reduction achieved by raising tax rates. But on the other hand, voters may not be very accurate in distinguishing between discretionary policy and cyclical effects of the budget; even professional economists cannot agree on an appropriate cyclical correction. We show below, however, that our results are qualitatively very robust to both the cyclically corrected and the uncorrected measures of the primary deficit.

As for types of cabinet, we focus on the number of parties in gov- 
ernment and their ideological bent. We distinguish between single party cabinets and coalition cabinets, composed of members of two or more of the national parties. For ideological alignment, we adopt a cabinet ideology indicator that is widely used in the political science literature. ${ }^{30}$

For this exercise, our definition of tight and loose fiscal policy is a generalization from that used above. A year of tight fiscal policy is one in which the change in the ratio of the primary deficit to GDP is less than or equal to -1.5 percentage points; and a year of loose policy is one in which the change in the same ratio is greater than or equal to 1.5 percentage points.

We use the same definition of success as above: a successful adjustment is a year of tight policy such that either it is followed by three years in which the average ratio of the primary deficit to GDP is at least 2 percentage points lower than in the tight year; or three years after the tight policy, the debt-to-GDP ratio is 5 percentage points lower than it was in that year.

\section{Results}

Table 6 illustrates the relative frequencies of the various outcomes as a function of government characteristics. Note that we distinguish successful and unsuccessful adjustments only for tight periods. The first column identifies the frequencies of particular government characteristics. For instance, the first entry in the column, 0.53 , identifies the frequency of single party cabinets in the panel of government-years, whereas the first entry in the second column presents the relative frequency with which cabinets of this type pursue loose policies. The other entries may be interpreted in a similar manner.

The table shows that the ideological orientation of government does not seem to have much influence on the frequency of loose and tight episodes. Although left-wing governments have a higher frequency of loose policies, they are also more likely to follow tight policies than right-wing governments. ${ }^{31}$ In fact, there are several examples of right-

30. This indicator is presented in Budge, Keman, and Woldendorp (1993) and is described below. See appendix A for further details on all definitions and sources.

31. This finding is consistent with that of Alesina, Roubini, and Cohen (1997). In their study of political business cycles in OECD countries, they use panel regressions 


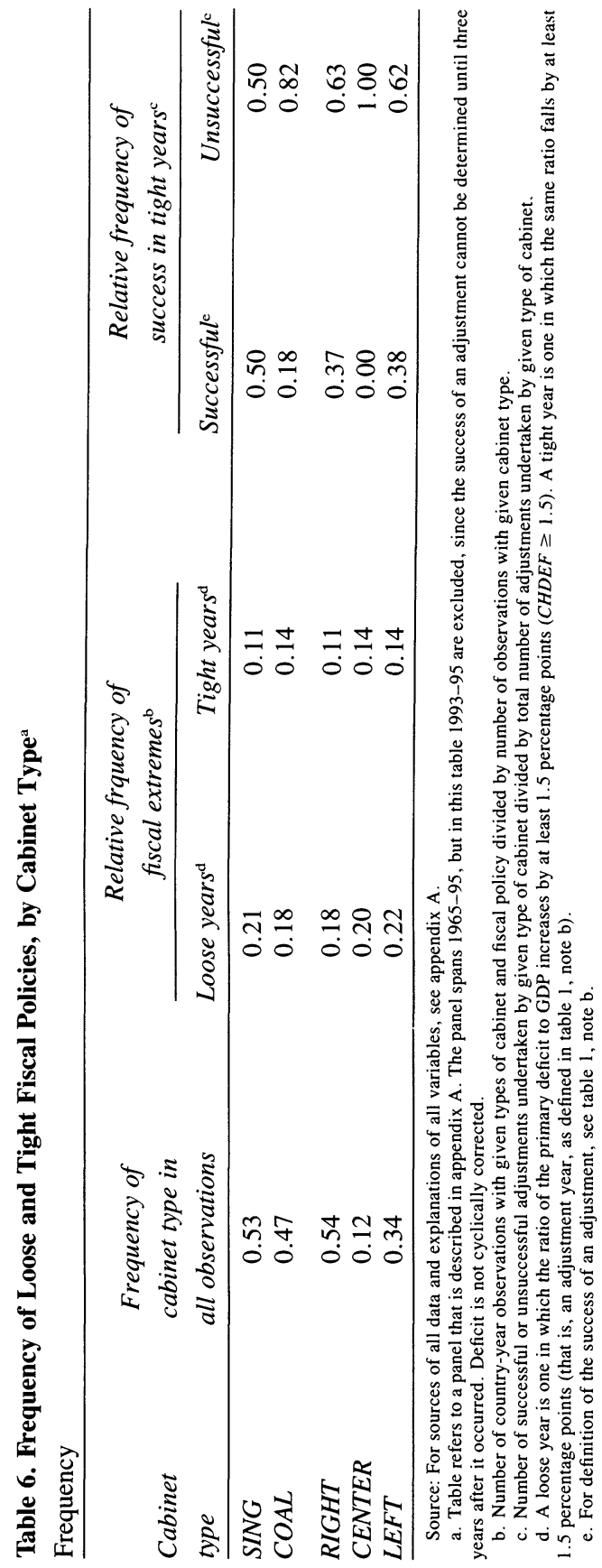


wing governments that run large deficits, including the two Reagan administrations in the United States in the 1980s and the Conservative government in Sweden in the late 1970s. ${ }^{32}$ In Italy during the 1970 s and 1980s, deficits occurred regardless of the political complexion of the cabinet. The table also indicates that the probability of successthat is, the ratio of successful adjustments to the total number of tight adjustments - is virtually identical for left-wing and right-wing governments.

Most interesting, the probability of success is much lower for centrist governments relative to right- and left-wing governments, and for coalition governments relative to single party governments. These observations are two sides of the same coin, since all centrist governments are coalition governments. Specifically, the table shows that coalition governments implement tight policies as often as do single party governments, but these initiatives almost never lead to long-lasting fiscal adjustments. The finding that fragmented governments have greater difficulty in permanently consolidating the budget and typically fail in their attempts to do so is validated empirically by several studies ${ }^{33}$ It is also consistent with theoretical models that emphasize the effect of a fragmented decision process on the timing of fiscal stabilizations. ${ }^{34}$

\section{Fiscal Adjustments and Changes in Government}

In this section we consider the electoral consequences of fiscal policy in general, and of fiscal adjustments in particular.

\section{Data}

For this exercise, in addition to the variables considered in the previous section, we need to define the instances when there is a change

to examine whether the average level of the budget deficit is higher for left- or rightwing cabinets, with inconclusive results.

32. These episodes inspired Persson and Svensson (1989), who model the incentive for a right-wing cabinet to run a deficit in order to reduce the level of government spending that future cabinets are able to finance.

33. See Grilli, Masciandaro, and Tabellini (1991); Alesina and Perotti (1995); Kontopoulos and Perotti (1997); Hallerberg and von Hagen (1997).

34. See, for example, Alesina and Drazen (1991); Spolaore (1993); Velasco (1996). 
in government. ${ }^{35} \mathrm{We}$ start from the set of all government terminations (TERM); that is, any instance in which a government ends, regardless of the reason. A government termination may or may not lead to a change in government. We consider two overlapping types of change in government: a change of prime minister $(P M C H)$ and a change in the ideological orientation of the cabinet (IDEOCH). These are dummy variables, equal to one when a change occurs. The two sets are distinct, so that in the United Kingdom, for example, the replacement of Margaret Thatcher by John Major is classified as $P M C H$ but not IDEOCH, while the replacement of John Major by Tony Blair is classified as both $\mathrm{PMCH}$ and IDEOCH. ${ }^{36}$ Changes of prime minister are more frequent than changes in ideology, because often the leadership of a major coalition party changes, and hence also the prime minister, although there is no accompanying change in the ideology of the cabinet overall. Note, however, that ideological changes are not simply a subset of changes of prime minister: the same prime minister might lead two successive coalition cabinets with compositions sufficiently different that they correspond to different ideologies. ${ }^{37} \mathrm{~A}$ third dummy variable $(A L L C H)$ is defined to be equal to one when a change either of ideology or of prime minister occurs. The number of positive observations of $A L L C H$ is higher than for either $P M C H$ or IDEOCH and smaller than for TERM.

The definition of change of prime minister change is selfexplanatory. In some cases when there is a change of prime minister but no change in the supporting coalition, the prime minister retired for health reasons rather than for any policy-related reason. There are only a handful of such cases, however, and we have verified that our results would not change if we eliminated these from our sample. We do not exclude cases when an incumbent prime minister chooses not to run, since that decision may in itself be an endogenous response to policy, and therefore excluding such observations would bias our results. For

35. Details of data sources and the construction of all variables are provided in appendix $\mathrm{A}$.

36. For the United States, we consider a change of president equivalent to a change of prime minister in all other countries. This implies that we classify a change in the party of the president as a change in ideology.

37. A change in the party composition of the cabinet is a necessary, but not a sufficient, condition for a change in cabinet ideology. 
example, a prime minister may choose not to run for another term if he is perceived as unpopular and unlikely to win. ${ }^{38}$

The definition of what constitutes an ideological change, by contrast, is not obvious. We have adopted and updated a measure commonly used by political scientists. This first classifies political parties on a left-right spectrum, according to "expert judgments" by political scientists. It then assigns an ideological index to a cabinet on the basis of the weights of the different parties that hold ministerial posts. ${ }^{39}$

The reappointment of the same party or coalition of parties to form a new cabinet may indicate that voters are satisfied with current policy. But the party composition of the cabinet is not the direct choice of the voters; instead, it results from postelectoral negotiations between parties whose relative strength does not fluctuate greatly over time. In some extreme cases, such as Japan, the political system makes a change in the ideological character of the cabinet very unlikely. Conversely, the replacement of a prime minister may reflect voters' dissatisfaction with the fiscal policies pursued under his leadership, even though they are not willing to bring the opposition parties to power. For our statistical results, we present two measures of changes in government: the broadest measure, $A L L C H$, and the more restricted IDEOCH.

Table 7 shows the relative frequency of positive values for the dummy variables TERM, ALLCH, PMCH, and IDEOCH in the full sample and for each country. Out of a total of 631 usable observations, 291 are cabinet terminations, 164 are changes of prime minister, and ninety-five are changes in ideology. The country with the most terminations is Italy, with twenty-nine. The countries with the least are the Netherlands and the United States, with eleven terminations each. ${ }^{40}$ Italy also has the highest number of changes of prime minister, while Austria, Canada, and Germany have the lowest number.

38. We also eliminate the transition from Ronald Reagan to George Bush in the United States, since Reagan was barred, under the Constitution, from running for a third term.

39. Budge, Keman, and Woldendorp (1993). See appendix A for a more detailed exposition of our procedures.

40. One might expect a relative frequency of 0.25 for TERM for the United States, since the Constitution fixes the presidential term at four years. Note, however, that our sample includes the assassination of John F. Kennedy and the resignation of Richard Nixon, both of which are counted as terminations in table 7 . 
Table 7. Frequency of Government Terminations and Cabinet Changes, by Country, 1965-95

Frequency

\begin{tabular}{|c|c|c|c|c|}
\hline Country & TERM & $A L L C H$ & $\mathrm{PMCH}$ & IDEOCH \\
\hline Australia & 0.53 & 0.22 & 0.22 & 0.14 \\
\hline Austria & 0.36 & 0.19 & 0.14 & 0.14 \\
\hline Belgium & 0.47 & 0.33 & 0.25 & 0.28 \\
\hline Canada & 0.33 & 0.14 & 0.14 & 0.00 \\
\hline Denmark & 0.58 & 0.33 & 0.22 & 0.28 \\
\hline Finland & 0.56 & 0.44 & 0.44 & 0.19 \\
\hline France & 0.53 & 0.42 & 0.39 & 0.14 \\
\hline Germany & 0.44 & 0.14 & 0.14 & 0.08 \\
\hline Greece & 0.33 & 0.28 & 0.28 & 0.17 \\
\hline Ireland & 0.42 & 0.25 & 0.22 & 0.14 \\
\hline Italy & 0.80 & 0.56 & 0.56 & 0.19 \\
\hline Japan & 0.58 & 0.33 & 0.33 & 0.03 \\
\hline Netherlands & 0.30 & 0.28 & 0.22 & 0.14 \\
\hline Norway & 0.44 & 0.33 & 0.28 & 0.30 \\
\hline Portugal & 0.53 & 0.37 & 0.32 & 0.32 \\
\hline Spain & 0.39 & 0.17 & 0.17 & 0.11 \\
\hline Sweden & 0.47 & 0.28 & 0.25 & 0.11 \\
\hline United Kingdom & 0.33 & 0.19 & 0.19 & 0.11 \\
\hline United States & 0.30 & 0.22 & 0.22 & 0.14 \\
\hline All countries ${ }^{\mathrm{b}}$ & 0.46 & 0.29 & 0.26 & 0.15 \\
\hline
\end{tabular}

Source: For sources of all data and explanations of all variables, see appendix A.

a. For each country, table gives mean of a given dummy variable across all years in the sample. Sample begins after 1965 for some countries; see appendix A.

b. Gives variable means for entire panel.

As mentioned above, we use the sample of changes irrespective of whether a transition to a new cabinet occurs by means of elections, cabinet reshuffling, or other procedures. In certain countries, such as the United States, almost all changes in government occur as a result of general elections, but in many other countries government resignations and coalition reshuffles take place without elections. ${ }^{41}$ We have examined whether our results differ substantially when we use only changes following elections, but find that they do not. Therefore we present results using changes following any type of termination, whether or not it follows an election.

Another important data issue concerns the timing of changes in government within the calendar year, relative to the fiscal year. Suppose

41. The exceptions for the United States in our sample are the replacements of John F. Kennedy by Lyndon Johnson and of Richard Nixon by Gerald Ford. 
Table 8. Correlations Among Deficit and Cabinet Change Variables ${ }^{a}$

Correlation coefficient

\begin{tabular}{lrccccc}
\hline & CHDEF & COCHDEF & TOTCHDEF & TERM & ALLCH & PMCH \\
\hline COCHDEF & 0.72 & 1.00 & & & & \\
TOTCHDEF & 0.79 & 0.60 & 1.00 & & & \\
TERM & 0.13 & 0.28 & 0.31 & 1.00 & & \\
ALLCH & 0.04 & 0.16 & 0.23 & 0.82 & 1.00 & \\
PMCH & 0.06 & 0.27 & 0.26 & 0.81 & 0.96 & 1.00 \\
IDEOCH & -0.05 & -0.11 & 0.18 & 0.38 & 0.55 & 0.36 \\
\hline
\end{tabular}

Source: For sources of all data and explanations of all variables, see appendix A.

a. Panel spans 1965-95, as described in appendix A. Correlations are among the residuals that result from regressing these variables on country dummies.

that a government terminates in June of year $t$. Should one consider the fiscal variables of year $t$ as before or after government termination? This choice clearly has implications for the correspondence between fiscal policies and the government changes that are seen as a response to those policies. We adopt the following simple convention: every termination that occurs between July 1 of year $t$ and June 30 of year $t+1$ is considered to fall in calendar year $t$; therefore it is considered contemporaneous to the fiscal outcomes of year $t$. In other words, the fiscal policy of year $t$ is regarded as a determinant of government collapses from July 1 of year $t$ to June 30 of year $t+1 . .^{42}$

We consider three measures of changes in the deficit: the change in the ratio of the primary deficit to GDP from year $t-1$ to year $t$ $(C H D E F)$; the average value of $C H D E F$ over the term of office of the current cabinet up to year $t$ (TOTCHDEF); and CHDEF corrected for the cycle (COCHDEF). The correlations in the panel among these definitions of changes in the deficit and the cabinet change variables are reported in table 8 .

Note the high positive correlations between the different definitions of the deficit. More important, increases in the contemporaneous deficit are weakly but positively correlated with changes in government. Cyclically corrected change in the deficit and change over the term of office are more strongly correlated with cabinet changes. Overall, these sim-

42. We have performed a sensitivity analysis on this definition and find that our results are qualitatively unaffected. For some reason, government terminations are much more frequent in the first and last quarters of the year that in the middle two, and therefore moving the break point between April and October makes very little difference. 
Figure 1. Frequency of Cabinet Changes and Fiscal Adjustments ${ }^{a}$

Frequency of cabinet changes

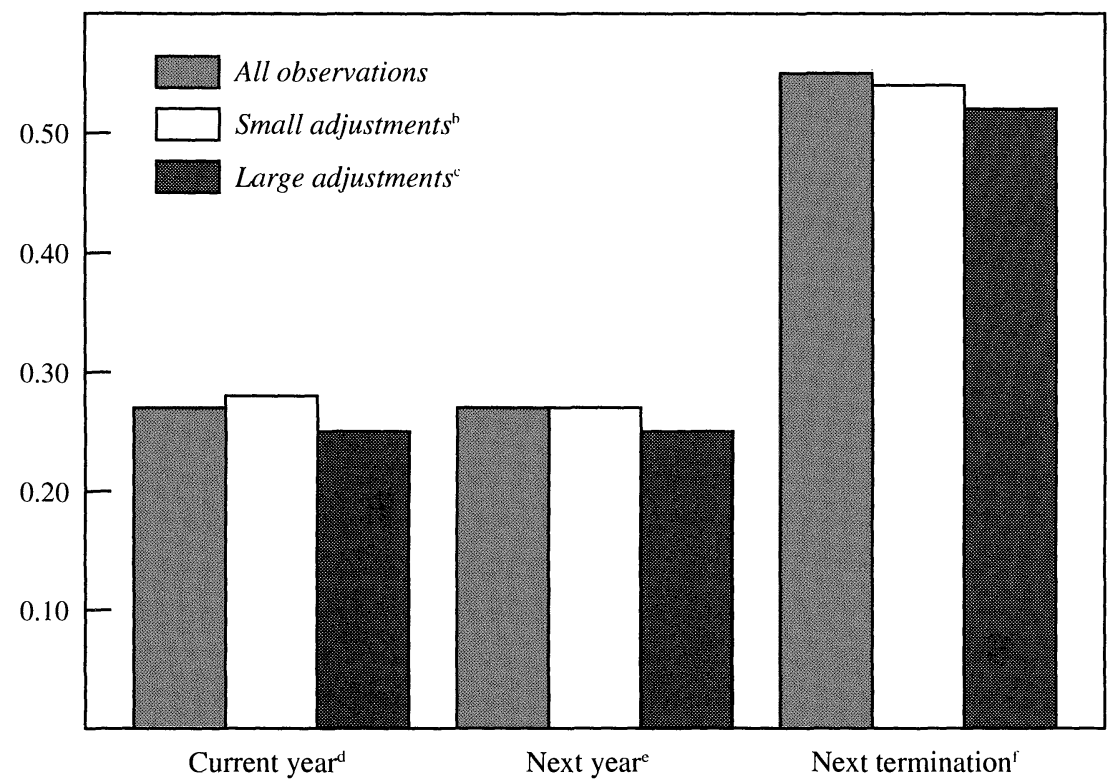

Source: For sources of all data and explanations of all variables, see appendix A

a. Figure gives mean of dummy variable $A L L C H$ for various subsets of country-years in a panel that spans $1960-95$ and is described in appendix $\mathrm{A}$.

b. Panel is restricted to country-years in which $-1.5<C H D E F<0$.

c. Includes only country-years in which $C H D E F \leq-1.5$.

d. Bars for small and large fiscal adjustments refer to government changes occurring in the same year as the adjustment.

e. Bars for small and large fiscal adjustments refer to government changes occurring in the year following the adjustment

f. Refers to government changes occurring at the next termination (TERM). Panel is restricted to country-years that are followed within three years by a termination.

ple row correlations provide no evidence that loose fiscal policies lead to electoral success or that tight policies lead to defeat.

\section{Fiscal Adjustments and the Timing of Changes in Government}

We now focus on the timing of changes in government relative to the timing of fiscal adjustments of different intensities. Recall that government changes $(A L L C H)$ are a subset of terminations (TERM). Figure 1 plots the frequency of $A L L C H$ against deficit reductions of different sizes, showing contemporaneous changes in government, changes that occur one year after the fiscal adjustment, and changes in 
the next termination. In each case, the figure presents the frequency of changes for the whole sample, for small deficit reductions, and for large reductions.

The first of the left-hand set of bars shows that the frequency of $A L L C H$ for the entire sample is about 0.3 , indicating a change about every three years, on average, as one would expect from table 7 . The second bar in this set indicates the frequency of changes following small adjustments (that is, 0 to 1.5 percentage point reductions in the debtto-GDP ratio), and the third bar indicates the frequency of changes following large adjustments (that is, reductions of at least 1.5 percentage points). If governments fell more often than average following periods of fiscal tightening, the second and third bar of each set would be higher than the first. In fact, irrespective of the timing of change after adjustment, we find no evidence that this is the case.

The right-hand set of bars samples only those year that are followed within three years by a termination. ${ }^{43}$ The first bar in this set, for example, indicates that of all the country-year observations that are followed within three years by a termination, about half are followed by a termination that is a change in government. Once again, we find no evidence that deficit reduction policies increase the frequency of political change.

Figure 2 presents equivalent results for changes in ideology $(I D E O C H)$. At first glance it appears that ideological changes are more frequent after large fiscal adjustments than after small adjustments, and are more frequent than average overall. However, closer examination of the data suggests that the evidence is inconclusive. A more detailed breakdown of adjustment size reveals that the highest frequency of IDEOCH does not occur after the largest adjustments (that is, a deficit reduction of more than 2.5 percentage points of GDP), but rather in an intermediate range, closer to a 1.5 percentage point cut in the deficitto-GDP ratio. ${ }^{44}$ The results obtained by using the cyclically corrected measure of change in the deficit are virtually identical to those presented in figures 1 and 2 .

43. Our sample includes cabinet tenures of up to five years. We have verified that our results do not change if we consider the next termination, whatever the time it takes to occur, rather than a termination in the next three years.

44. These results are not shown here, but are available upon request. 
Figure 2. Frequency of Changes in Cabinet Ideology and Fiscal Adjustments ${ }^{a}$

Frequency of cabinet changes

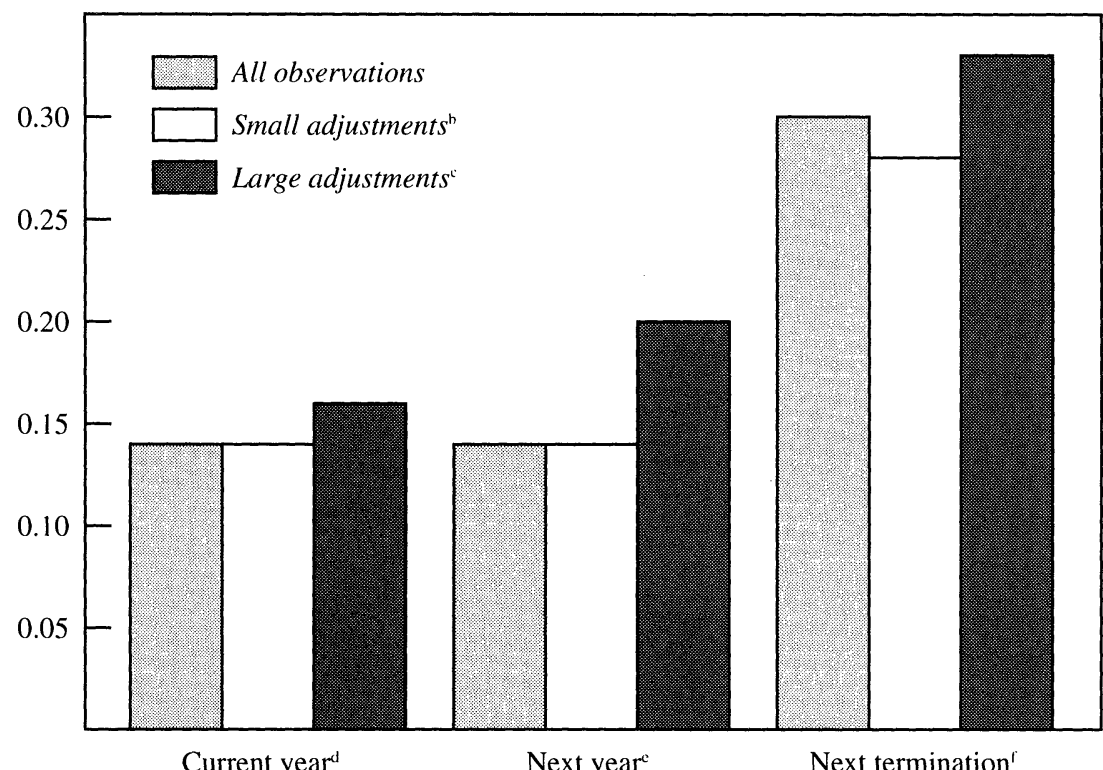

Source: For sources of all data and explanations of all variables, see appendix A.

a. Figure gives mean of dummy variable $I D E O C H$ for various subsets of country-years in a panel that spans 1960-95 and is described in appendix $\mathrm{A}$.

b. Panel is restricted to country-years in which $-1.5<C H D E F<0$

c. Includes only country-years in which $C H D E F \leq-1.5$.

d. Bars for small and large fiscal adjustments refer to ideological changes occurring in the same year as the adjustment.

e. Bars for small and large fiscal adjustments refer to ideological changes occurring in the year following the adjustment.

f. Refers to ideological changes occurring at the next termination (TERM). Panel is restricted to country-years that are followed within three years by a termination.

\section{Composition of Adjustments and the Timing of}

\section{Changes in Government}

We argue above that the most successful (that is, long lasting) adjustments involve spending cuts rather than tax increases. Political rhetoric suggests that spending cuts, especially in welfare and social security programs, are very unpopular. However, the structure of current spending in most OECD countries-in Europe, in particular-is such that it is virtually impossible to achieve significant spending cuts without affecting these components of the budget. Whereas in the early 1960s government consumption represented more than half of spending 
Figure 3. Frequency of Cabinet Changes and Expenditure- and Tax-Based Adjustments"

Frequency of cabinet changes

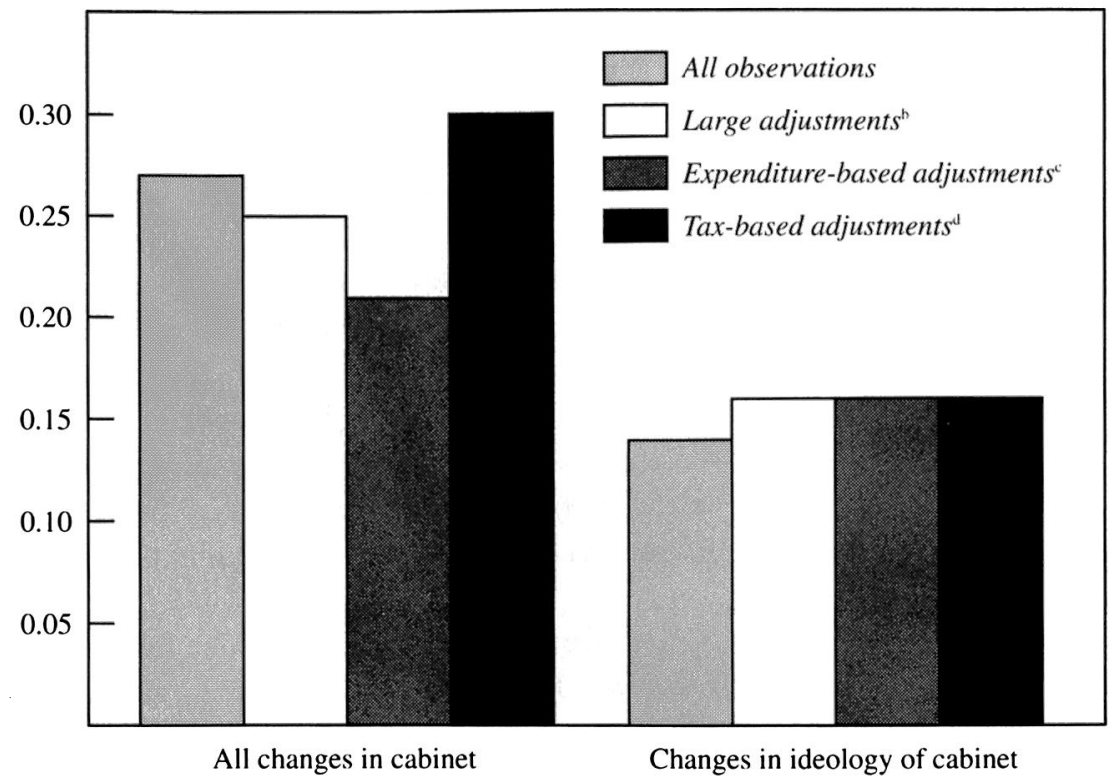

Source: For sources of all data and explanations of all variables, see appendix $\mathrm{A}$

a. Figure gives either the mean of a dummy variable indicating all changes in government $(A L L C H)$ or the mean of a dummy variable indicating changes in government ideology $(I D E O C H)$, as specified, for various subsets of the country-years in a panel that spans 1960-95 and is described in appendix A.

b. Panel is restricted to country-years in which $C H D E F \leq-1.5$

c. Includes only country-years' in which $C H D E F \leq-1.5$ and the change in expenditures $(C H E X P)$ is less than its median value in large adjustment years.

d. Includes only country-years in which $C H D E F \leq-1.5$ and $C H E X P$ is greater than its median value in large adjustment years.

in most OECD countries, over the past thirty years the transfer and welfare components of the budget have grown much faster than government consumption, so that relative size of the two components as a fraction of total spending has been reversed.

Figure 3 relates the composition of adjustments to contemporaneous government changes. We focus on large adjustments, defined as deficit reductions of 1.5 percentage points of GDP or more.$^{45} \mathrm{We}$ also divide

45. We choose this threshold of deficit reduction to isolate really large adjustments while maintaining a fair number of observations; a threshold of 2.5 percentage points would yield far fewer observations. Our results are not highly sensitive to the choice of threshold, however. 
these large adjustments into "spending-based" adjustments (those with spending cuts greater than the median for large adjustments) and "taxbased" adjustments (those with spending cuts below the median). Figure 3 shows, first, that in years with a fiscal adjustment of at least 1.5 percentage points of GDP, the frequency of $A L L C H$ is lower than the overall frequency in the panel, as seen also in figure $1 .{ }^{46} \mathrm{Second}$, at least in the case of contemporaneous effects, governments seem to survive in office more often when they cut spending than when they increase taxes.

Figure 4 focuses on government wages and is organized in the same way as figure 3 . It shows that governments that choose to cut government wages more have a higher probability of survival. The result is particularly striking for $A L L C H$. Figure 5 examines transfers in the same manner. While the results for $A L L C H$ show no difference between "transfer-based"' and other adjustments, the results for IDEOCH suggest that the probability of survival is higher for governments that do not cut transfers.

In summary, our results up to this point offer no evidence that voters punish governments for reducing deficits. In the case of large adjustments, it seems that if a government relies mostly on spending cutsand on cuts in government wages, in particular-it is less likely to fall.

\section{Fiscal Adjustments and the Probability of Change in Government}

In this section we estimate the probability of change in government as a function of several economic variables and characteristics of the cabinet. Our purpose is to determine the effect of changes in fiscal stance on the probability of a cabinet's survival. We run probit regressions on our panel with a measure of cabinet change (ALLCH or $I D E O C H)$ as the dependent variable. For each definition of change in cabinet, we estimate the effect of a 1 percentage point change in the deficit-to-GDP ratio, according to one of three definitions: using change in the uncorrected deficit $(C H D E F)$, using change in the cyclically

46. In other words, the first and second bars of each set in figure 3. are equivalent to the first and third bars of each set in figure 1, measuring the contemporaneous change in the cabinet. 
Figure 4. Frequency of Cabinet Changes and Government Wage- and Non-Wage-Based Adjustments ${ }^{\mathrm{a}}$

Frequency of cabinet changes

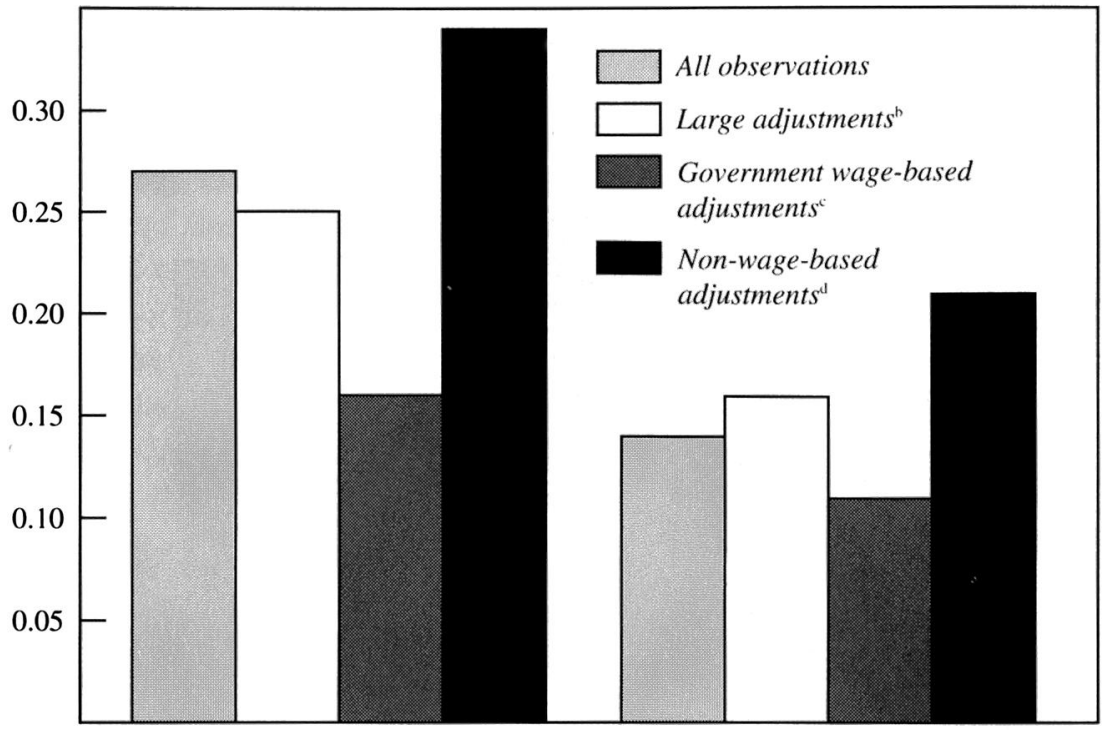

All changes in cabinet

Changes in ideology of cabinet

Source: For sources of all data and explanations of all variables, see appendix A.

a. Figure gives either the mean of a dummy variable indicating all changes in government $(A L L C H)$ or the mean of a dummy variable indicating changes in government ideology $(I D E O C H)$, as specified, for various subsets of the country-years in a panel that spans 1960-95 and is described in appendix A.

b. Panel is restricted to country-years in which $C H D E F \leq-1.5$.

c. Includes only country-years in which $C H D E F \leq-1.5$ and the change in government wages $(C H C G W)$ is less than its median value in large adjustment years.

d. Includes only country-years in which $C H D E F \leq-1.5$ and $C H C G W$ is greater than its median value in large adjustment years.

corrected deficit $(C O C H D E F)$, or average change in the ratio during the tenure of the current cabinet (TOTCHDEF).

In addition, we introduce three other macroeconomic indicators as right-hand-side variables: GDP growth $(\triangle G D P)$, the growth rate of the unemployment rate $(\triangle U N R)$, and the inflation rate $(I N F L)$. The motivation for these controls is straightforward: GDP growth, unemployment, and inflation are the standard macroeconomic variables considered in the literature on the determinants of voting behavior. ${ }^{47}$ Although

47. For the United States, see, in particular, Kramer (1971); Fair (1978); Alesina and Rosenthal (1995). For other OECD countries, see Lewis-Beck (1988); Powell and Whitten (1993). 
Figure 5. Frequency of Cabinet Changes and Transfer- and Non-Transfer-Based Adjustments ${ }^{a}$

Frequency of cabinet changes

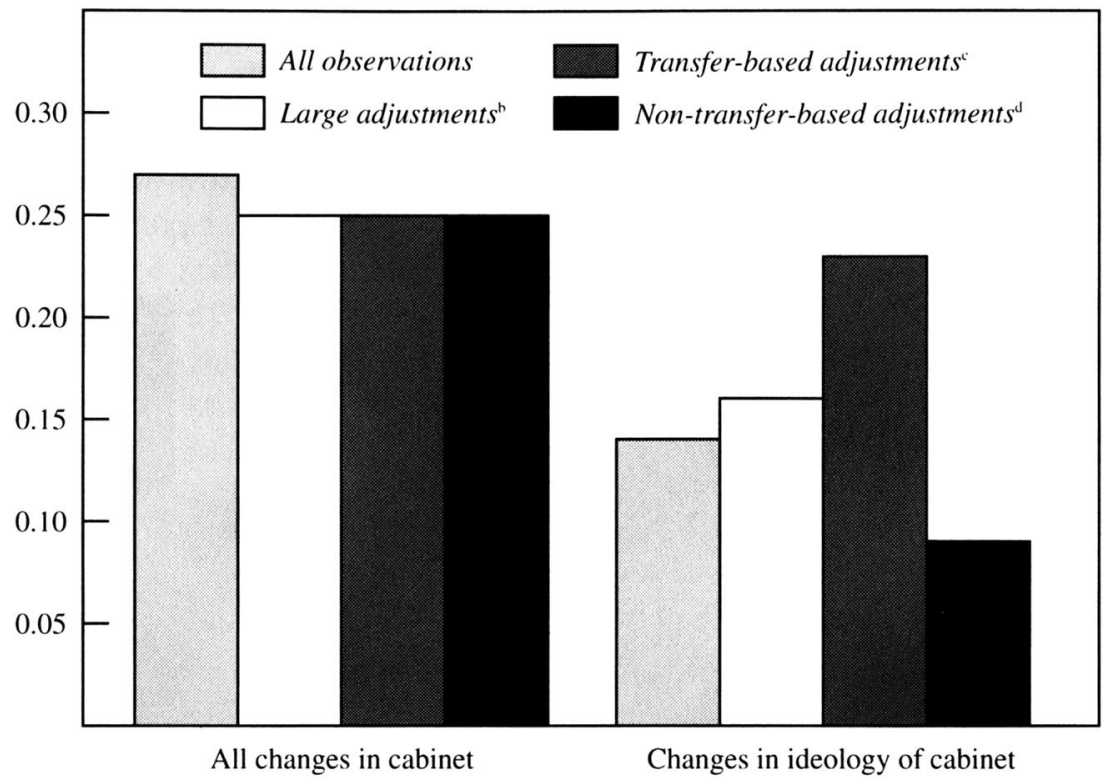

Source: For sources of all data and explanations of all variables, see appendix A.

a. Figure gives either the mean of a dummy variable indicating all changes in government $(A L L C H)$ or the mean of a dummy variable indicating changes in government ideology $(I D E O C H)$, as specified, for various subsets of the country-years in a panel that spans 1960-95 and is described in appendix A.

b. Panel is restricted to country-years in which $C H D E F \leq-1.5$

c. Includes only country-years in which $C H D E F \leq-1.5$ and the change in transfers $(C H T R F)$ is less than its median value in large adjustment years.

d. Includes only country-years in which $C H D E F \leq-1.5$ and $C H T R F$ is greater than its median value in large adjustment years.

the level of unemployment varies across countries it is very persistent in many countries ${ }^{48}$ Hence we use the rate of growth of the unemployment rate rather than its level as a dependent variable. ${ }^{49}$ The inflation rate is intended to capture the conventional wisdom and well-documented fact that people dislike inflation and may punish governments for it. ${ }^{50}$

We also control for three characteristics of cabinets that may affect

48. For a classic study on unemployment persistence in Europe, see Summers and Blanchard (1990).

49. We have tried both using the rate of change of the unemployment rate and using the simple difference in the unemployment rate. The results are not affected by this distinction, and here we present only those using the rate of change.

50. See Shiller (1996) for empirical evidence. 
the likelihood of their political survival: number of years in power (DURAT); whether it is supported by a majority in parliament (MAJ); and whether it is of a coalition of two or more parties $(C O A L)$. The probability of a change in government should increase with tenure; and coalition governments and those not supported by a parliamentary majority should be weaker and more likely to collapse. ${ }^{51}$

Table 9 presents results of the probit specifications for the full sample. In each case, the deficit variable is statistically insignificant, irrespective of the way we measure changes in the deficit and in cabinets. This is a crucial finding: there is no evidence that fiscal profligacy is associated with longer survival in office.

The coefficients on growth and unemployment are insignificant, even though they display the expected signs in most cases. The coefficient on inflation has the expected sign and is statistically significant, whatever the specification: higher inflation increases the probability of a government change. These findings are consistent with the existing literature. For example, G. Bingham Powell Jr. and Guy Whitten and Martin Paldam consider elections in OECD countries and find insignificant effects of growth and unemployment on voting behavior. Kaare Strom and Martin Lipset obtain similar results on growth and unemployment but significant results on inflation, particularly from 1973. Michael Lewis-Beck's results on a smaller sample of countries are consistent with these. ${ }^{52}$

Our results on the political controls are highly consistent with conventional wisdom, as well as with the existing literature. On all of these variables the coefficients have the expected signs and are statistically significant. Ceteris paribus, coalition governments and minority governments are more likely to fall in any given period: a coalition government is about 11 to 15 percent more likely to fall than a single party government, while a majority cabinet has about an 8 to 11 percent lower probability of falling than a minority cabinet. The weakest type of government is thus an alliance of two or more parties that does not

51. See Powell and Whitten (1993).

52. Powell and Whitten (1993); Paldam (1991); Strom and Lipset (1984); LewisBeck (1988). The United States is an important exception to this pattern. There is a vast literature showing that the rate of GDP growth, and to a lesser extent unemployment and inflation, are important determinants of presidential elections; see, in particular, Kramer (1971); Fair (1978); Alesina and Rosenthal (1995). 
Table 9. Probit Regressions Predicting Cabinet Changes, Whole Sample ${ }^{a}$

\begin{tabular}{|c|c|c|c|c|c|c|}
\hline \multirow{2}{*}{$\begin{array}{l}\text { Independent } \\
\text { variable }\end{array}$} & \multicolumn{6}{|c|}{ Dependent variable } \\
\hline & $A L L C H$ & $A L L C H$ & $A L L C H$ & $I D E O C H$ & IDEOCH & IDEOCH \\
\hline$C H D E F$ & $\begin{array}{c}-0.020 \\
(-0.54) \\
-0.007\end{array}$ & & & $\begin{array}{c}-0.017 \\
(-0.39) \\
-0.004\end{array}$ & & \\
\hline COCHDEF & & $\begin{array}{c}0.009 \\
(0.26) \\
0.003\end{array}$ & & & $\begin{array}{c}-0.006 \\
(-0.16) \\
-0.001\end{array}$ & \\
\hline TOTCHDEF & & & $\begin{array}{r}0.015 \\
(0.34) \\
0.005\end{array}$ & & & $\begin{array}{r}-0.014 \\
(-0.26) \\
-0.003\end{array}$ \\
\hline$\triangle G D P^{\mathrm{b}}$ & $\begin{array}{c}-0.010 \\
(-0.34) \\
-0.003\end{array}$ & $\begin{array}{c}-0.005 \\
(-0.21) \\
-0.002\end{array}$ & $\begin{array}{c}-0.020 \\
(-0.69) \\
-0.006\end{array}$ & $\begin{array}{c}-0.026 \\
(-0.85) \\
-0.005\end{array}$ & $\begin{array}{c}-0.024 \\
(-0.80) \\
-0.005\end{array}$ & $\begin{array}{r}-0.044 \\
(-1.29) \\
-0.010\end{array}$ \\
\hline$\Delta U N R^{\mathrm{b}}$ & $\begin{array}{r}0.003 \\
(1.17) \\
0.001\end{array}$ & $\begin{array}{r}0.003 \\
(1.00) \\
0.001\end{array}$ & $\begin{array}{r}-0.001 \\
(-0.04) \\
-0.000\end{array}$ & $\begin{array}{r}0.001 \\
(0.46) \\
0.003\end{array}$ & $\begin{array}{c}0.001 \\
(0.38) \\
0.002\end{array}$ & $\begin{array}{r}0.001 \\
(0.23) \\
0.002\end{array}$ \\
\hline$I N F L^{\mathrm{b}}$ & $\begin{array}{c}0.029 \\
(2.61) \\
0.010\end{array}$ & $\begin{array}{c}0.030 \\
(2.64) \\
0.010\end{array}$ & $\begin{array}{c}0.031 \\
(2.59) \\
0.010\end{array}$ & $\begin{array}{c}0.026 \\
(2.05) \\
0.006\end{array}$ & $\begin{array}{c}0.026 \\
(2.05) \\
0.006\end{array}$ & $\begin{array}{c}0.023 \\
(1.69) \\
0.005\end{array}$ \\
\hline DURAT & $\begin{array}{r}0.185 \\
(3.31) \\
0.061\end{array}$ & $\begin{array}{r}0.186 \\
(3.31) \\
0.061\end{array}$ & $\begin{array}{c}0.181 \\
(3.22) \\
0.060\end{array}$ & $\begin{array}{c}0.228 \\
(3.64) \\
0.049\end{array}$ & $\begin{array}{c}0.228 \\
(3.64) \\
0.049\end{array}$ & $\begin{array}{c}0.224 \\
(3.57) \\
0.049\end{array}$ \\
\hline$C O A L$ & $\begin{array}{c}0.456 \\
(3.63) \\
0.150\end{array}$ & $\begin{array}{r}0.465 \\
(3.72) \\
0.153\end{array}$ & $\begin{array}{r}0.461 \\
(3.62) \\
0.152\end{array}$ & $\begin{array}{r}0.511 \\
(3.44) \\
0.112\end{array}$ & $\begin{array}{c}0.516 \\
(3.49) \\
0.114\end{array}$ & $\begin{array}{c}0.512 \\
(3.39) \\
0.113\end{array}$ \\
\hline MAJ & $\begin{array}{r}-0.246 \\
(-1.72) \\
-0.083\end{array}$ & $\begin{array}{r}-0.242 \\
(-1.69) \\
-0.082\end{array}$ & $\begin{array}{r}-0.264 \\
(-1.82) \\
-0.090\end{array}$ & $\begin{array}{c}-0.403 \\
(-2.43) \\
-0.096\end{array}$ & $\begin{array}{c}-0.402 \\
(-2.42) \\
-0.096\end{array}$ & $\begin{array}{r}-0.447 \\
(-2.66) \\
-0.109\end{array}$ \\
\hline \multicolumn{7}{|c|}{ Summary statistic } \\
\hline $\begin{array}{l}\text { Log likelihood } \\
N\end{array}$ & $\begin{array}{c}-326.71 \\
583\end{array}$ & $\begin{array}{c}-326.56 \\
582\end{array}$ & $\begin{array}{c}-318.01 \\
564\end{array}$ & $\begin{array}{c}-230.89 \\
583\end{array}$ & $\begin{array}{c}-203.85 \\
582\end{array}$ & $\begin{array}{c}-155.93 \\
564\end{array}$ \\
\hline
\end{tabular}

Source: For sources of all data and explanations of all variables, see appendix A

a. Probit regressions include a constant and use the panel of country-years described in appendix A. Each set of entries includes the coefficient, the $t$ statistic (in parentheses), and the marginal effect of a one unit change in the regressor (evaluated at the means of all regressors).

b. When TOTCHDEF is included as the deficit change variable, given variables are replaced by $\triangle T O T G D P, \triangle T O T U N R$, and $\triangle T O T I N F L$, as appropriate, and corresponding coefficients are reported. 
hold a majority in the legislature. Not surprisingly, the probability of a change in government increases with tenure.

The results in table 9 are robust to various sensitivity analyses. For example, they do not change when we drop the political or economic control variables, either as a group or individually, or when we introduce country dummies. ${ }^{53} \mathrm{We}$ also check whether, conditional on a given year being a termination, the probability of a change in prime minister or ideology is affected by the fiscal policy variable, by isolating the sample of years when there was a termination and running the specifications presented in the table. Once again, we find no evidence of an effect of deficit cuts on the probability of government survival, either with the corrected deficit or with the uncorrected deficit.

An important possibility is that there is a lag between the adjustment and the electoral fortunes of the government. We run the same probit specifications but lag each of the independent variables by one year. We construct similar variables for change of cabinet in the next termination, whenever it occurs. Our results confirm that cabinets that cut deficits are not punished by voters at any time in the future. This is true irrespective of the measure of deficit or change in government considered.

In table 10 we replicate the probit regressions of table 9 but restrict the sample to adjustment years. In other words, we include in the panel only country-years in which the deficit change variable assumes a negative sign; the magnitudes of the observed deficit reductions still vary. In all specifications, the coefficient of the deficit variable has a positive sign. In most cases, the coefficient is statistically insignificant, with the exception of the third column, where it is significant. The fact that the coefficient on the deficit is always positive indicates that, if anything, more radical adjustments are associated with a lower probability of a change in government. When we run this specification for the subsample of country-years in which the deficit increases, the coefficients are insignificant. That is, there is no evidence that looser fiscal policies contribute to political survival.

53. In particular, we examine the joint significance of the economic variables using a likelihood ratio test. At standard confidence levels, we find that we cannot reject the hypothesis that growth $(\triangle G D P)$ and unemployment growth $(\triangle U N R)$ are jointly insignificant for either $A L L C H$ or IDEOCH. However, the hypothesis that growth, unemployment, and inflation are jointly insignificant is strongly rejected, whichever indicator of change is used. 
Table 10. Probit Regressions Predicting Cabinet Changes, Sample of Adjustment Years $^{\mathrm{a}}$

\begin{tabular}{|c|c|c|c|c|c|c|}
\hline \multirow{2}{*}{$\begin{array}{l}\text { Independent } \\
\text { variable } \\
\end{array}$} & \multicolumn{6}{|c|}{ Dependent variable } \\
\hline & $A L L C H$ & $A L L C H$ & $A L L C H$ & $I D E O C H$ & IDEOCH & IDEOCH \\
\hline CHDEF & $\begin{array}{c}0.100 \\
(1.19) \\
0.032\end{array}$ & & & $\begin{array}{c}0.042 \\
(0.46) \\
0.009\end{array}$ & & \\
\hline COCHDEF & & $\begin{array}{c}0.106 \\
(1.17) \\
0.034\end{array}$ & & & $\begin{array}{c}0.004 \\
(0.04) \\
0.001\end{array}$ & \\
\hline TOTCHDEF & & & $\begin{array}{c}0.245 \\
(2.16) \\
0.076\end{array}$ & & & $\begin{array}{c}0.200 \\
(1.57) \\
0.041\end{array}$ \\
\hline$\Delta G D P^{\mathrm{b}}$ & $\begin{array}{c}-0.028 \\
(-0.68) \\
-0.009\end{array}$ & $\begin{array}{c}-0.014 \\
(-0.35) \\
-0.004\end{array}$ & $\begin{array}{c}-0.044 \\
(-0.98) \\
-0.014\end{array}$ & $\begin{array}{c}-0.073 \\
(-1.48) \\
-0.016\end{array}$ & $\begin{array}{c}-0.045 \\
(-0.95) \\
-0.010\end{array}$ & $\begin{array}{c}-0.043 \\
(-0.82) \\
-0.009\end{array}$ \\
\hline$\Delta U N R^{\mathrm{b}}$ & $\begin{array}{c}0.003 \\
(0.59) \\
0.001\end{array}$ & $\begin{array}{r}0.006 \\
(1.31) \\
0.002\end{array}$ & $\begin{array}{c}-0.002 \\
(-0.48) \\
-0.001\end{array}$ & $\begin{array}{c}-0.003 \\
(-0.48) \\
-0.001\end{array}$ & $\begin{array}{c}-0.001 \\
(-0.29) \\
-0.000\end{array}$ & $\begin{array}{r}-0.002 \\
(-0.26) \\
-0.000\end{array}$ \\
\hline$I N F L^{\mathrm{b}}$ & $\begin{array}{r}0.035 \\
(2.11) \\
0.011\end{array}$ & $\begin{array}{c}0.038 \\
(2.17) \\
0.012\end{array}$ & $\begin{array}{c}0.042 \\
(2.45) \\
0.013\end{array}$ & $\begin{array}{c}0.026 \\
(1.43) \\
0.006\end{array}$ & $\begin{array}{c}0.018 \\
(0.91) \\
0.004\end{array}$ & $\begin{array}{c}0.022 \\
(1.15) \\
0.004\end{array}$ \\
\hline DURAT & $\begin{array}{c}0.196 \\
(2.42) \\
0.064\end{array}$ & $\begin{array}{c}0.186 \\
(2.35) \\
0.060\end{array}$ & $\begin{array}{c}0.088 \\
(1.08) \\
0.027\end{array}$ & $\begin{array}{c}0.158 \\
(1.75) \\
0.034\end{array}$ & $\begin{array}{c}0.188 \\
(2.16) \\
0.004\end{array}$ & $\begin{array}{c}0.164 \\
(1.81) \\
0.033\end{array}$ \\
\hline$C O A L$ & $\begin{array}{c}0.688 \\
(3.68) \\
0.222\end{array}$ & $\begin{array}{c}0.576 \\
(3.09) \\
0.185\end{array}$ & $\begin{array}{c}0.689 \\
(3.62) \\
0.216\end{array}$ & $\begin{array}{c}0.646 \\
(2.93) \\
0.143\end{array}$ & $\begin{array}{c}0.672 \\
(2.98) \\
0.145\end{array}$ & $\begin{array}{c}0.848 \\
(3.62) \\
0.180\end{array}$ \\
\hline$M A J$ & $\begin{array}{r}-0.284 \\
(-1.26) \\
-0.096\end{array}$ & $\begin{array}{r}-0.192 \\
(-0.87) \\
-0.063\end{array}$ & $\begin{array}{c}-0.436 \\
(-1.94) \\
-0.146\end{array}$ & $\begin{array}{c}-0.488 \\
(-1.90) \\
-0.121\end{array}$ & $\begin{array}{c}-0.445 \\
(-1.71) \\
-0.106\end{array}$ & $\begin{array}{r}-0.699 \\
(-2.60) \\
-0.173\end{array}$ \\
\hline
\end{tabular}

Summary statistic

\begin{tabular}{lcccccc} 
Log likelihood & -155.93 & -159.54 & -154.00 & -115.78 & -115.53 & -110.93 \\
$N$ & 289 & 296 & 292 & 289 & 296 & 292 \\
\hline
\end{tabular}

Source: For sources of all data and explanations of all variables, see appendix A.

a. Probit regressions include a constant. Panel is described in appendix A, but in this table is restricted to country-years in which the deficit-to-GDP ratio is reduced $(C H D E F<0)$. Each set of entries includes the coefficient, the $t$ statistic (in parentheses), and the marginal effect of a one unit change in the regressor (evaluated at the means of all regressors).

b. When TOTCHDEF is included as the deficit change variable, given variables are replaced by $\triangle T O T G D P, \triangle T O T U N R$, and $\triangle T O T I N F L$, as appropriate, and corresponding coefficients are reported. 
Since most of the large cases of large fiscal adjustments occurred in the 1980s and 1990s, we also split the sample into the periods up to 1974 and from 1975 onward. We find that changes in the deficit do not affect chances of political survival in either subsample. Moreover, when we consider only periods of adjustment, larger cuts in the deficit are associated with political survival when $A L L C H$ is used. This result is stronger for the period that starts in 1975.

In table 11 we examine whether adjustments that rely primarily on spending cuts, particularly on government wages and transfers, decrease the probability of government survival and find that they do not. This table is organized similarly to table 9 . The first independent variable is contemporaneous change in the deficit (CHDEF). PEXP (defined in appendix $A$ ) is equal to one for a given observation if it satisfies two criteria: the deficit-to-GDP ratio is cut by more than 1.5 percentage points, and the cut in total public expenditures is larger than the median cut in expenditures for the sample of large adjustments (that is, deficit-to-GDP reductions of at least 1.5 percentage points). The dummy variables $P T R F$ and $P C G W$ similarly isolate large reductions in transfer payments and in government wage consumption, respectively. With these dummy variables we isolate large adjustments that rely mostly on spending cuts, that is, those that are more likely to have a discernible effect on the well-being of the voters. The results in table 11 offer no evidence whatsoever that this type of adjustment is politically costly. All of the coefficients are statistically insignificant, but the negative sign of the coefficients when $A L L C H$ is the dependent variable is consistent with a higher probability of government survival for large adjustments on the spending side.

In summary, the regressions described in this section provide no evidence that the probability of survival falls as cabinets pursue deficitreducing policies. Rather, we find weak evidence that during sharp adjustments that rely primarily on spending cuts in general, and on the major components of government wages and transfers, in particular, the probability of government survival may even increase.

\section{Fiscal Adjustments and the Popularity of the Government}

Politicians are concerned about popularity and often change policies as a result of unfavorable opinion polls. In this section we examine the 
Table 11. Adding Adjustment Composition Dummies to Regressions Predicting Cabinet Changes ${ }^{\mathrm{a}}$

\begin{tabular}{|c|c|c|c|c|c|c|}
\hline \multirow{2}{*}{$\begin{array}{l}\text { Independent } \\
\text { variable }\end{array}$} & \multicolumn{6}{|c|}{ Dependent variable } \\
\hline & $A L L C H$ & $A L L C H$ & $A L L C H$ & $I D E O C H$ & IDEOCH & $I D E O C H$ \\
\hline$C H D E F$ & $\begin{array}{r}-0.041 \\
(-0.98) \\
-0.013\end{array}$ & $\begin{array}{c}-0.030 \\
(-0.75) \\
-0.010\end{array}$ & $\begin{array}{r}-0.036 \\
(-0.92) \\
0.012\end{array}$ & $\begin{array}{c}-0.003 \\
(-0.07) \\
-0.001\end{array}$ & $\begin{array}{c}-0.006 \\
(-0.14) \\
-0.001\end{array}$ & $\begin{array}{c}-0.020 \\
(-0.46) \\
-0.004\end{array}$ \\
\hline$\Delta G D P$ & $\begin{array}{r}-0.008 \\
(-0.33) \\
-0.003\end{array}$ & $\begin{array}{r}-0.008 \\
(-0.30) \\
-0.002\end{array}$ & $\begin{array}{c}-0.005 \\
(-0.20) \\
-0.002\end{array}$ & $\begin{array}{c}-0.026 \\
(-0.86) \\
-0.006\end{array}$ & $\begin{array}{c}-0.028 \\
(-0.90) \\
-0.006\end{array}$ & $\begin{array}{c}-0.025 \\
(-0.82) \\
-0.005\end{array}$ \\
\hline$\Delta U N R$ & $\begin{array}{r}0.003 \\
(1.17) \\
0.001\end{array}$ & $\begin{array}{c}0.003 \\
(1.05) \\
0.001\end{array}$ & $\begin{array}{c}0.003 \\
(1.08) \\
0.001\end{array}$ & $\begin{array}{c}0.001 \\
(0.45) \\
0.000\end{array}$ & $\begin{array}{c}0.002 \\
(0.56) \\
0.000\end{array}$ & $\begin{array}{c}0.001 \\
(0.44) \\
0.000\end{array}$ \\
\hline$I N F L$ & $\begin{array}{c}0.029 \\
(2.62) \\
0.010\end{array}$ & $\begin{array}{c}0.029 \\
(2.63) \\
0.010\end{array}$ & $\begin{array}{c}0.029 \\
(2.56) \\
0.001\end{array}$ & $\begin{array}{c}0.026 \\
(2.06) \\
0.006\end{array}$ & $\begin{array}{c}0.025 \\
(2.01) \\
0.006\end{array}$ & $\begin{array}{c}0.026 \\
(2.03) \\
0.006\end{array}$ \\
\hline DURAT & $\begin{array}{c}0.190 \\
(3.38) \\
0.062\end{array}$ & $\begin{array}{c}0.186 \\
(3.32) \\
0.061\end{array}$ & $\begin{array}{c}0.192 \\
(3.41) \\
0.063\end{array}$ & $\begin{array}{r}0.226 \\
(3.61) \\
0.049\end{array}$ & $\begin{array}{c}0.228 \\
(3.65) \\
0.049\end{array}$ & $\begin{array}{c}0.230 \\
(3.66) \\
0.050\end{array}$ \\
\hline$C O A L$ & $\begin{array}{c}0.465 \\
(3.69) \\
0.153\end{array}$ & $\begin{array}{c}0.463 \\
(3.68) \\
0.152\end{array}$ & $\begin{array}{c}0.464 \\
(3.69) \\
0.152\end{array}$ & $\begin{array}{c}0.508 \\
(3.42) \\
0.111\end{array}$ & $\begin{array}{c}0.504 \\
(3.39) \\
0.111\end{array}$ & $\begin{array}{c}0.513 \\
(3.45) \\
0.113\end{array}$ \\
\hline$M A J$ & $\begin{array}{r}-0.257 \\
(-1.79) \\
-0.087\end{array}$ & $\begin{array}{c}-0.249 \\
(-1.74) \\
-0.084\end{array}$ & $\begin{array}{c}-0.254 \\
(-1.77) \\
-0.086\end{array}$ & $\begin{array}{c}-0.398 \\
(-2.39) \\
-0.095\end{array}$ & $\begin{array}{c}-0.399 \\
(-2.41) \\
-0.095\end{array}$ & $\begin{array}{r}-0.405 \\
(-2.44) \\
-0.097\end{array}$ \\
\hline$P E X P$ & $\begin{array}{c}-0.232 \\
(-1.16) \\
-0.072\end{array}$ & & & $\begin{array}{c}0.147 \\
(0.68) \\
0.034\end{array}$ & & \\
\hline PTRF & & $\begin{array}{c}-0.128 \\
(-0.81) \\
-0.041\end{array}$ & & & $\begin{array}{c}0.142 \\
(0.81) \\
0.032\end{array}$ & \\
\hline$P C G W$ & & & $\begin{array}{c}-0.233 \\
(-1.55) \\
-0.073\end{array}$ & & & $\begin{array}{c}-0.060 \\
(-0.35) \\
-0.013\end{array}$ \\
\hline \multicolumn{7}{|l|}{ Summary statistic } \\
\hline $\begin{array}{l}\text { Log likelihood } \\
N\end{array}$ & $\begin{array}{c}-326.02 \\
583\end{array}$ & $\begin{array}{c}-326.37 \\
583\end{array}$ & $\begin{array}{c}-325.49 \\
583\end{array}$ & $\begin{array}{c}-230.66 \\
583\end{array}$ & $\begin{array}{c}-230.56 \\
583\end{array}$ & $\begin{array}{c}-230.82 \\
583\end{array}$ \\
\hline
\end{tabular}


relation between fiscal adjustments and government popularity, as measured by opinion polls. The difference between data on popularity polls and data on actual elections is that the former are much more frequent and thus may capture voters' responses to fiscal adjustments more quickly.

\section{Data}

Our data on popularity come from a variety of sources. The main source is the European Commission's Eurobarometer survey, which asks a sample of citizens in each European Union country a series of questions concerning political orientation. For the present purpose, the question of particular interest is: "Which party would you vote for if general elections were held tomorrow?' By aggregating the response for the parties in and out of government, we construct a variable measuring the share of total voters who would likely vote for the parties in government, if elections were held tomorrow. For Norway and Sweden, which joined the European Community in the middle of the sample period, and also for Australia, Canada, and the United States, we use domestic sources that ask questions very similar to that in the Eurobarometer survey. Thus we obtain a sample of sixteen countries (Austria, Finland, and Japan are omitted from our original sample) with yearly observations for the period 1975-93. The variable $P O P C H$ is defined as the year-to-year change in government popularity. ${ }^{54}$

\section{Results}

Table 12 reports the correlation matrix for several variables of interest. In order to correct for country-specific effects, we present correlations between the residuals of regressions of each variable on country dummies. The correlation between change in the deficit and change in popularity polls is positive.

We then perform regression analysis with $P O P C H$ on the left-hand side, and on the right-hand side, the economic and institutional variables used in the probit regressions predicting cabinet changes. The results are presented in table 13 . We find no effects of deficit changes on change in government popularity. None of the other economic var-

54. Full details of sources and construction are provided in appendix A. 
Table 12. Correlations Among Deficit, Cabinet Change, and Popularity Variables ${ }^{a}$

Correlation coefficient

\begin{tabular}{lrcccccc}
\hline & CHDEF & COCHDEF & TOTCHDEF & TERM & ALLCH & PMCH & IDEOCH \\
\hline COCHDEF & 0.96 & 1.00 & & & & & \\
TOTCHDEF & 0.79 & 0.75 & 1.00 & & & & \\
TERM & -0.29 & -0.17 & -0.04 & 1.00 & & & \\
ALLCH & -0.30 & -0.28 & -0.03 & 0.83 & 1.00 & & \\
PMCH & -0.31 & -0.30 & -0.06 & 0.77 & 0.95 & 1.00 & \\
IDEOCH & -0.16 & -0.12 & 0.04 & 0.64 & 0.73 & 0.53 & 1.00 \\
POPCH & 0.15 & 0.21 & 0.33 & 0.18 & 0.01 & -0.12 & 0.37 \\
\hline
\end{tabular}

Source: For sources of all data and explanations of all variables, see appendix A

a. Panel includes sixteen countries-as specified in the section on popularity data in appendix A-over the period 1975-93. Correlations are among the residuals that result from regressing these variables on country dummies.

iables is significant. Various sensitivity analyses and specification tests do not alter this picture. This absence of evidence that government popularity is systematically affected by changes in the deficit is consistent with our previous findings.

\section{Causality}

Our results thus far can be summarized by the statement that government collapses are not significantly more probable after deficit reductions or less probable after deficit increases. This finding is open to two different interpretations. The first is that electorates are fiscally "responsible," that is, they do not like excessive deficits and understand that fiscal adjustments are sometimes necessary. As a consequence, such electorates do not punish governments that cut the deficit. The second interpretation is that voters dislike tax increases and spending cuts, but the cabinets that choose to implement fiscal adjustments are so popular on other issues that they can afford unpopular fiscal policies. In this section we try to discover which interpretation is more likely.

If the second interpretation were correct, governments would try to "get away" with fiscal adjustments at the beginning of their terms. They would suffer a temporary loss of popularity, but would recover in time for the next election. In a sense, this is a version of the political business cycle theory of William Nordhaus, according to which governments follow expansionary policies just before elections and adjust 
Table 13. Regressions Explaining Government Popularity ${ }^{\mathrm{a}}$

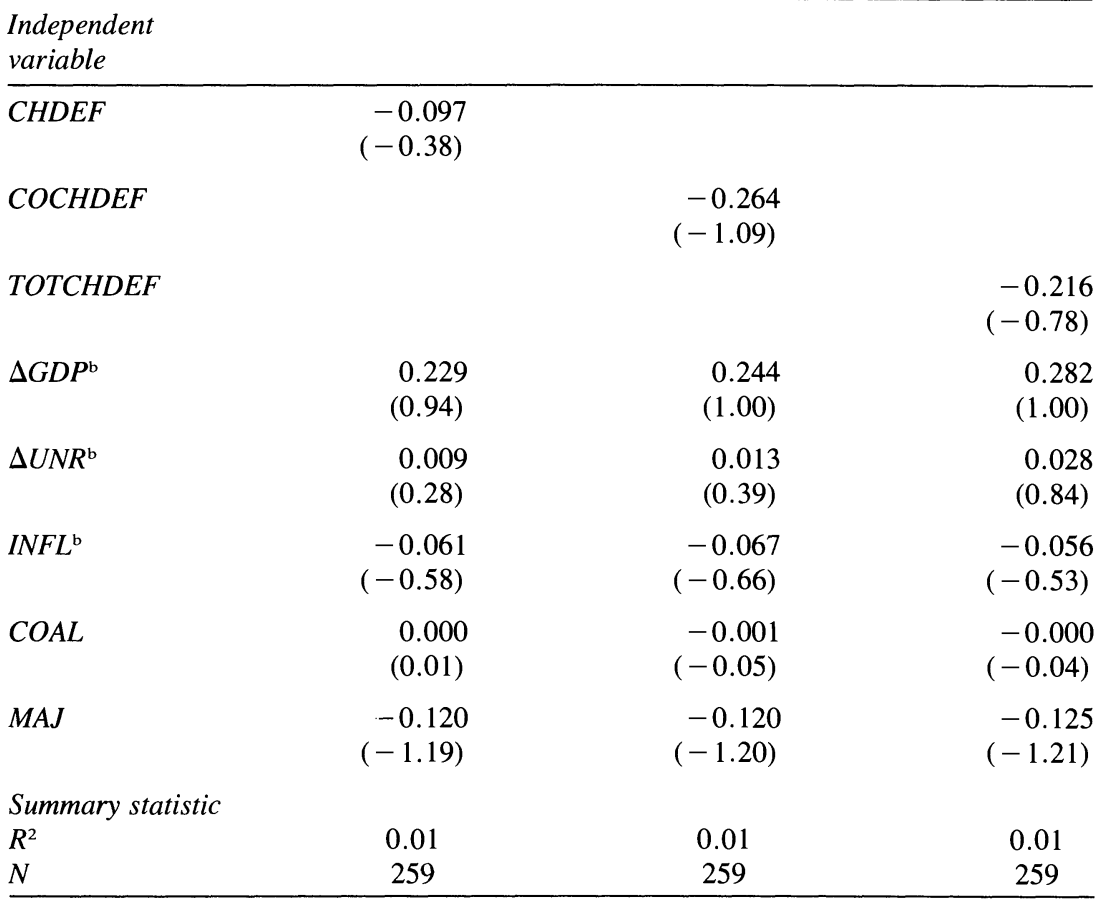

Source: For sources of all data and explanations of all variables, see appendix A.

a. Dependent variable is $P O P C H$, the percentage point change in government popularity (see appendix A). Regressions include a constant. Panel includes sixteen countries-as specified in the section on popularity data in appendix A-over the period 1975-93. Heteroskedasticity-consistent $t$ statistics are in parentheses.

b. When TOTCHDEF is included as the deficit change variable, given variables are replaced by $\triangle T O T G D P, \triangle T O T U N R$, and $\triangle T O T I N F L$, as appropriate, and corresponding coefficients are reported.

after they are reelected. ${ }^{55}$ This argument has two implications that can be tested empirically: first, that fiscal contractions tend to be concentrated at the beginning of a political term; and second, that fiscal contractions should be followed by temporary declines in the popularity of the cabinet.

The results in the previous section reject the second implication. In regard to the first implication, in the first line of table 14 we report the average tenure for the whole sample, and for the subsample of governments whose tenures include small or large adjustments. The first row of table 14 shows no evidence that deficit cuts are concentrated in the

55. Nordhaus (1975). For an extensive discussion of the related literature, see Alesina, Roubini, and Cohen (1997). 
Table 14. Average Tenure and Popularity of Cabinets That Undertake Fiscal Adjustments $^{\text {a }}$

Units as indicated

\begin{tabular}{|c|c|c|c|c|c|}
\hline \multirow[b]{2}{*}{ Variable } & \multirow[b]{2}{*}{$\begin{array}{c}\text { All } \\
\text { observations }\end{array}$} & \multicolumn{2}{|c|}{$\begin{array}{c}\text { Deficit not cyclically } \\
\text { corrected }\end{array}$} & \multicolumn{2}{|c|}{$\begin{array}{c}\text { Deficit cyclically } \\
\text { corrected }\end{array}$} \\
\hline & & $\begin{array}{c}\text { Small } \\
\text { adjustments }^{\mathrm{b}}\end{array}$ & $\begin{array}{c}\text { Large } \\
\text { adjustments }^{\mathrm{c}}\end{array}$ & $\begin{array}{c}\text { Small } \\
\text { adjustments }^{\mathrm{b}}\end{array}$ & $\begin{array}{c}\text { Large } \\
\text { adjustments }^{\mathrm{c}}\end{array}$ \\
\hline$D U R A T$ & $\begin{array}{c}1.99 \\
(0.07)\end{array}$ & $\begin{array}{c}2.04^{*} \\
(0.12)\end{array}$ & $\begin{array}{c}1.89 \\
(0.13)\end{array}$ & $\begin{array}{c}1.96 \\
(0.12)\end{array}$ & $\begin{array}{c}1.93 \\
(0.30)\end{array}$ \\
\hline POPLEV/100 & $\begin{array}{c}0.45 \\
(0.01)\end{array}$ & $\begin{array}{c}0.46 \\
(0.01)\end{array}$ & $\begin{array}{c}0.44 \\
(0.01)\end{array}$ & $\begin{array}{c}0.46 \\
(0.01)\end{array}$ & $\begin{array}{c}0.44 \\
(0.02)\end{array}$ \\
\hline $\begin{array}{l}\text { Summary statis } \\
N\end{array}$ & 259 & 82 & 45 & 89 & 41 \\
\hline
\end{tabular}

first year after a termination. Although the average number of years in office is lower for large adjustments than for the whole sample, the difference is not significant. This is true whether or not we correct for the business cycle in the definitions of adjustments. Thus neither implication of the political business cycle argument is verified in our sample.

More broadly, if it is the case that only strong governments implement unpopular fiscal adjustments, they should do so when their popularity is particularly high. However, there is no evidence that government popularity is higher than average immediately before fiscal adjustments. Table 14 shows that the average popularity level for the whole sample is 44.5 percent, while the average popularity at the beginning of calendar years with large adjustments is actually slightly lower, at 44.4 percent. Average popularity is a little higher than for the whole sample immediately before small fiscal adjustments ( 46.3 percent). ${ }^{56}$ The results are similar for both uncorrected and cyclically corrected measures of the deficit.

56. There are two reasons why all of these values are below 50 percent. First, all of our popularity data refer to the period 1975-93, when several OECD countries had quite unpopular governments. Second, the popularity figure gives the percentage of respon- 
Another way to address the issue of causality is to consider adjustments when the timing is not chosen by the cabinet; that is, adjustments that are unavoidable given the circumstances. In table 15 we estimate the reaction to such exogenous adjustments by instrumenting for the change in the deficit. We use as instruments for the change in deficit the short- and long-term real interest rates, the debt-to-GDP ratio at the beginning of the year, the change in the debt-to-GDP ratio in the three years before the observation, and the average growth of real GDP in the G7 countries. These instruments are, for the most part, significant and display the expected signs in explaining change in the deficit.

As often is the case, the choice of instruments is problematic and imperfect. Therefore the results of this exercise should be taken with caution. The real interest rates and the average growth rate for the G7 countries probably do not directly affect popularity, but may indicate times when it is easier (or more urgent) to reduce the deficits. Average G7 growth is correlated with the growth rates of individual countries, but as discussed above, the latter is not highly correlated with government popularity or survival, except in the United States. The level and growth of the national debt indicate the necessity to engage in a fiscal adjustment, but are unlikely to affect the survival of the cabinet directly. As before, changes in the deficit do not significantly affect the government's chances of survival. The patterns and statistical significance of all the other coefficients are similar to those in the probit regressions above.

Another, potentially fruitful, way to address exogeneity is to investigate the effect on government survival of fiscal adjustments imposed on a country by outside authorities. Obvious examples are the adjustments imposed by the convergence criteria for the European Monetary Union under the Maastricht treaty. It would be interesting to examine whether voters react differently to fiscal policies imposed by international constraints than to those chosen independently by their national governments. Casual observation suggests that the response to the effects of the Maastrich treaty has been varied. In Italy very large tax increases, some of them explicitly targeted to monetary union (such as 
Table 15. Probit Regressions Predicting Cabinet Changes, Instrumental Variable Estimation $^{\mathrm{a}}$

\begin{tabular}{lcr}
\hline \multirow{2}{*}{$\begin{array}{l}\text { Independent } \\
\text { variable }\end{array}$} & \multicolumn{2}{c}{ Dependent variable } \\
\cline { 2 - 3 } CHDEF & ALLCH & IDEOCH \\
& -0.079 & -0.011 \\
& $(-0.55)$ & $(-0.07)$ \\
SGDP & -0.026 & -0.002 \\
& -0.023 & -0.037 \\
SUNR & $(-0.66)$ & $(-0.90)$ \\
& -0.007 & -0.008 \\
& 0.001 & 0.001 \\
INFL & $(0.38)$ & $(0.30)$ \\
& 0.000 & 0.000 \\
& 0.050 & 0.038 \\
DURAT & $(2.98)$ & $(1.980)$ \\
& 0.016 & 0.008 \\
COAL & 0.172 & 0.197 \\
& $(2.55)$ & $(2.54)$ \\
& 0.056 & 0.041 \\
MAJ & 0.178 & 0.356 \\
& $(1.18)$ & $(1.97)$ \\
Summary statistic & 0.058 & 0.074 \\
Log likelihood & -0.274 & -0.382 \\
$N$ & $(-1.58)$ & $(-1.88)$ \\
\hline
\end{tabular}

Source: For sources of all data and explanations of all variables, see appendix A.

a. Probit regressions include a constant and use the panel of country-years described in appendix A. Each set of entries includes the coefficient, the $t$ statistic (in parentheses, and the marginal effect of a one unit change in the regressor (evaluated at the means of all regressors. CHDEF is instrumented using RINTRT, DEBT, CHDEBT, and $\triangle G D P G 7$. In the first stage regression, $\bar{R}^{2}=0.10$

"the Europe tax"), have been accepted relatively easily by the public. ${ }^{57}$ In France, by contrast, the conservative government's attempt to trim the welfare state during 1995-97 generated riots and cost it reelection.

When we try to determine whether the response of electorates in European Union countries to fiscal adjustments in the 1980s and 1990s is different from their responses to other adjustments, we find the evi-

57. It should be added, however, that Italian fiscal adjustments have largely avoided structural spending cuts on government wages, welfare, or social security. 
dence inconclusive. There are some problems with this approach, however. First, it is not always clear which policies are induced by the Maastricht treaty and which are not, especially as one goes further back in time. Second, since in recent years the decision to reduce deficits has essentially been identified with the decision to join the European Monetary Union, it is not clear to what extent Maastricht adjustments are truly exogenous.

\section{Concluding Comments}

Fiscal adjustments do not always cause recessions. On the contrary, fiscal consolidations prompted by a fiscal crisis and achieved by trimming government spending often have expansionary effects. Furthermore, governments do not seem to be systematically punished at the ballot box for engaging in fiscal adjustments, nor do they loose popularity, as measured by opinion polls. In principle, one can think of two explanations for this result. One is that voters do not like fiscal profligacy. The other is that governments are particularly skillful at choosing the appropriate moments to implement unpopular policies. While it is difficult to decide definitively, we conclude in favor of the first interpretation.

If it is true that fiscal adjustments do not imply high political costs, why are they so politically charged and difficult? One possible answer is that successful fiscal adjustments imply cuts in public wages and in transfers, including social security, directly affecting two constituencies that are very powerful in many countries: public sector employees and pensioners.

For demographic reasons, and because of the generosity of many public pension schemes, pensioners today are more numerous, longer lived, and wealthier than a couple of decades ago, and they have ample time to engage in political action. In many countries, pensioners represent a large fraction of union members. Therefore, as a constituency, pensioners have political influence beyond their share in the voting population. Indeed, the political influence of the union movement goes well beyond the fact that its members are voters. The approval of the unions is sought before any fiscal maneuver is approved and implemented by the government in many countries, including Italy, the Scandi- 
navian countries, and to some extent, Germany. Moreover, the union movement has recourse to forms of political action, such as general strikes, that can have serious sociopolitical consequences. Our results indicate, however, that governments that are willing to "bite the bullet' and persist in certain types of fiscal adjustment, despite union opposition, are not systematically punished at the ballot box.

Another-not mutually exclusive-explanation could be " political risk aversion." If politicians are unsure about the electoral consequences of a decisive fiscal adjustment, they might prefer not to "rock the boat' unless absolutely necessary, for example, because of fiscal stress. In other words, the political uncertainty associated with fiscal adjustments may deter policymakers from pursuing them more often, particularly in election years.

APPENDIX A

\section{Data}

OUR SAMPLE PERIODS are 1960-95 for the fiscal and cabinet change data and 1975-93 for the popularity data. The data set includes the following OECD countries: Australia, Austria, Belgium, Canada, Denmark, Finland, France, Germany, Greece, Ireland, Italy, Japan, the Netherlands, Norway, Portugal, Spain, Sweden, the United Kingdom, and the United States. Note that Greece, Spain, and Portugal are covered only from the mid-1970s, when they became pluralist democracies.

\section{Cabinet Data}

For the period 1960-95, cabinet data are from Budge, Keman, and Woldendorp (1993) and subsequent updates. For 1995 data, we use Banks and others (1996). We assemble data for Greece, Portugal, and Spain from Banks and others (1996), in accordance with the criteria used by Budge, Keman, and Woldendorp (1993), since the latter do not cover these countries. 
Given that the main interest of the paper is the electoral response to fiscal adjustment, the relevant electoral period is moved forward half a year relative to the fiscal data. For example, cabinet terminations and changes designated "1993" correspond to changes that occurred between July 1, 1993 and June 30, 1994. When more than one cabinet termination or change occurs in a given year, we apply the following rules:

-If there was no termination during the previous year, the incumbent cabinet has the same characteristics as the cabinet that was in power the previous year.

- If there was a termination during the year before and an election this year, the cabinet that faced the election is considered the cabinet of this year and the election is the reason for its termination.

- If there was a termination the year before but there was no election this year, we take the longest lasting cabinet of this year and the reason for its termination.

The cabinet variables are defined as follows:

DURAT Duration: integer number of years that a cabinet has been in power, up to the current year. A cabinet that falls during its first year in power is counted as 1 ; the maximum tenure in the sample is 5 .

SING Single party: dummy variable equal to 1 if a single party cabinet is in power.

COAL Coalition: dummy variable equal to 1 if a coalition cabinet-that is, including ministers from two or more parties-is in power.

MAJ Majority: dummy variable equal to 1 if the cabinet has majority support in parliament. Majority cabinets may be single party, minimal winning coalitions, or surplus coalitions; the second and third types imply an overlap of MAJ and COAL.

TERM Government termination: dummy variable equal to 1 in any year in which a government ends, regardless of the reason. A termination may or may not involve a "change" in cabinet ideology or prime minister.

IDEOCH Change in ideology of cabinet: dummy variable equal to 1 if there is a change in the ideology index between the current year and the next. The ideology index locates a 
cabinet on a right-left scale, as follows: 1 indicates that the share of right-wing parties in government-or of supporting parties in parliament, in cases where parties explicitly support a cabinet without holding office-is equal to or greater than two-thirds; 2 indicates that the shares of right and center parties are each between onethird and two-thirds; 3 indicates that the share of the center parties is larger than one-half, or that left- and right-wing parties form a government with neither dominant; 4 and 5 correspond to 1 and 2 in favor of leftwing parties. For the United States, a Democrat president is classified as 5, and a Republican as 1 .

$P M C H \quad$ Change of prime minister: dummy equal to 1 if there is a change of prime minister (or president, for the United States).

$A L L C H \quad$ Change of ideology or prime minister: dummy variable equal to 1 if either $I D E O C H$ or $P M C H$ is equal to 1.

RIGHT Right-wing cabinet: dummy variable equal to 1 if the cabinet in power scores 1 or 2 on the ideology index described under IDEOCH.

CENTER Cabinet at center of political spectrum: dummy variable equal to 1 if the cabinet in power scores 3 on the ideology index described under IDEOCH.

LEFT Left-wing cabinet: dummy variable equal to 1 if the cabinet in power scores 4 or 5 on the ideology index described under IDEOCH.

\section{Popularity Data}

We have popularity data for sixteen countries - that is, those listed above excluding Austria, Finland, and Japan-over the period 197593. For countries in the European Union, our main source is the European Commission's Eurobarometer, various issues; data for Greece are available from 1979, and for Portugal and Spain, from 1986. Exceptions are data on Sweden, which are from SIFO Research and Consulting, as provided by the Swedish Social Science Data Service, Goteborg; and on Norway, which are from the Norwegian Gallup Institute 
and Opinion A/S (from 1989), as provided by Norwegian Social Science Data Service, Bergen. Data for Australia are from the Australian Gallup poll, as provided by the Australian National University in Canada; for Canada, from the Canadian Institute of Public Opinion and Insight Canada Research (for 1992 and 1993), as provided by the Carleton University Library Data Centre, Ottawa; and for the United States, from the Gallup Organization's Gallup Monthly Poll, August 1995.

Change in popularity is constructed as follows. For each countryyear, we note which parties were represented in the cabinet, consistent with the cabinet data explained above. We then compute the percentage of respondents who said that they would vote for one of the parties in the cabinet, if elections were held soon (poll questions are almost always phrased in terms of elections to be held today or tomorrow). Virtually all of the surveys chosen as sources of popularity data are collected in November and December. Thus we can use change in popularity to measure the response to fiscal policy pursued within the calendar year.

The popularity variables are defined as follows:

POPLEV Level of popularity of parties represented in cabinet: percentage of respondents expressing support for one of the parties in cabinet at the end of the calendar year. For a given year, the cabinet is the same as that used to compute IDEOCH and ALLCH.

$\mathrm{POPCH} \quad$ Change in popularity of the parties represented in cabinet: change in the popularity level during the calendar year. If the governing party or coalition changes between time $t-1$ and time $t$, the $P O P C H$ assigned to $t$ is the change in popularity of the party in power at time $t$.

\section{National Accounts Data}

Aggregate macroeconomic data, and fiscal data, in particular, are taken from Organisation for Economic Co-operation and Development, Economic Outlook, 1997. They cover the period 1960-95. These economic variables are defined as follows:

CHDEF Change in deficit: percentage point change in the ratio of the primary deficit to GDP. 
CHEXP Change in public expenditures: percentage point change in the ratio of primary expenditures to GDP.

CHREV Change in public revenues: percentage point change in the ratio of public revenues to GDP.

CHTRF Change in transfers: percentage point change in the ratio of transfers to GDP.

CHSUB Change in subsidies: percentage point change in the ratio of subsidies to GDP.

CHCGW Change in government wages: percentage point change in the ratio of government wages to GDP.

CHCGNW Change in government expenditures other than wages: percentage point change in the ratio of public expenditures excluding government wages to GDP.

CHINV Change in public investment: percentage point change in the ratio of public investment to GDP.

COCHEXP Change in government expenditures (CHEXP), corrected for the cycle.

COCHREV Change in public revenues (CHREV), corrected for the cycle.

COCHDEF Change in the primary deficit $(C H D E F)$, corrected for the cycle: calculated as COCHEXP less COCHREV.

TOTCHDEF Average change in deficit during tenure: average percentage point change in the deficit over the years that the current cabinet has been in power, up to the current year. That is, the average of $C H D E F$ for the years from the last termination up to the current year.

DEBT Public debt: public debt as a percentage of GDP at the beginning of the fiscal year.

CHDEBT Change in public debt: percentage point change in $D E B T$ over the past three years $(t-3$ to $t)$.

$\triangle G D P \quad$ Rate of growth of real GDP, percent.

$\triangle T O T G D P$ Average growth during tenure: average growth rate from the time when a cabinet came to power, up to current year, percent.

$\triangle G D P G 7 \quad$ Growth of $\mathrm{G} 7$ countries: weighted average growth rate of the G7 countries, percent.

$\triangle G D P g 7$ Growth relative to the $\mathrm{G} 7$ countries: calculated as $\triangle G D P$ less $\triangle G D P G 7$. 
UNR Unemployment rate, percent.

$\triangle U N R \quad$ Growth of the unemployment rate, percent: $\left(U N R_{t} / U N R_{t-1}-1\right) \times 100$.

$\triangle T O T U N R$ Average unemployment growth during tenure: average annual growth rate of unemployment rate from beginning of cabinet's tenure to current year, percent.

UNRg7 Unemployment rate relative to the G7 countries: unemployment rate less the GDP-weighted average of the G7 unemployment rate, percentage points.

INFL Inflation: rate of change of the GDP deflator, percent.

TOTINFL Average inflation during tenure: average rate of inflation from the beginning of cabinet's tenure to current year, percent.

PEXP Spending-based adjustment: dummy variable equal to 1 when following two conditions hold: first, there is a large adjustment $(C H D E F \leq-1.5)$; and second, CHEXP is less than its median across all years in which a large adjustment occurs.

PTRF Transfer-based adjustment: dummy variable equal to 1 when following two conditions hold: first, there is a large adjustment $(C H D E F \leq-1.5)$; and second, CHTRF is less than its median across all years in which a large adjustment occurs.

PCGW Government wage-based adjustment: dummy variable equal to 1 when the following two conditions hold: first, there is a large adjustment $(C H D E F \leq-1.5)$; and second, $C H C G W$ is less than its median across all years in which a large adjustment occurs.

$\Delta I N V \quad$ Investment growth: rate of growth of real private business investment, percent.

$\triangle C O N S \quad$ Consumption growth: rate of growth of real private consumption, percent.

NINTRTg7 Relative nominal interest rate: long nominal interest rate (ten-year treasury notes) of a given country less the GDP-weighted average of long nominal interest rates in the G7 countries, percentage points.

RINTRT Real interest rate: ten-year interest rate minus the growth rate of the GDP deflator, percent. 
RINTRTg7 Relative real interest rate: ten-year real interest rate of a given country less the GDP-weighted average of real interest rates in the $\mathrm{G} 7$ countries.

$\triangle E F X C H R T$ Rate of change of effective exchange rate, percent. A positive value indicates appreciation.

$T B \quad$ Trade balance: the trade balance as a percentage of GDP. $\triangle U L C \quad$ Growth of unit labor costs: rate of growth of unit labor costs in manufacturing, percent.

$\triangle V A U L C \quad$ Rate of growth of the ratio of the value-added deflator for manufactured exports to the unit labor cost, percent. PSH Profit share: profits as a percentage of total income.

\section{Cyclical Adjustment}

Our methodology follows Blanchard (1990b). For each country, total primary expenditures and total revenues are corrected for the cycle by running OLS regressions of spending and revenues, respectively, on a constant, a time trend for the period 1960-75, a time trend for the period 1976-93 period, and the unemployment rate:

$$
\begin{aligned}
& \text { EXP }_{t}=\alpha_{0}+\alpha_{1}\left(\text { TREND }_{60-75}\right)+\alpha_{2}\left(\text { TREND }_{76-93}\right)+\alpha_{3}(U N R)_{t}+\epsilon, \\
& \text { REV }_{t}=\beta_{0}+\beta_{1}\left(\text { TREND }_{60-75}\right)+\beta_{2}\left(\text { TREND }_{76-93}\right)+\beta_{3}(U N R)_{t}+\epsilon .
\end{aligned}
$$

We then compute the cyclically adjusted aggregates as the original aggregate less the estimated coefficient on the unemployment rate times the change in the unemployment rate:

$$
\begin{aligned}
& \text { COCHEXP }_{t}=\text { CHEXP }_{t}-\hat{\alpha}_{3}\left(U N R_{t}-U N R_{t-1}\right), \\
& \text { COCHREV }_{t}=\text { CHREV }_{t}-\hat{\beta}_{3}\left(U N R_{t}-U N R_{t-1}\right) .
\end{aligned}
$$

These aggregates attempt to measure the levels of public expenditure and revenue that would have prevailed had the unemployment rate not changed relative to the previous year. This procedure corrects for change in fiscal policy due to short-run fluctuations and approximates to policymakers' choices of spending and revenue levels. The difference between cyclically corrected changes in expenditures $(C O C H E X P)$ and in revenues (COCHREV) is the cyclically corrected change in the fiscal deficit (COCHDEF). 


\section{Comments and Discussion}

Maurice Obstfeld: This is the latest in a series of illuminating papers by Alesina, Perotti, and several coauthors. The research has advanced the understanding of fiscal adjustment by focusing on the composition of fiscal changes. Are taxes raised or are government outlays cut? And in the latter case, do cuts fall on government investment or on public sector wages and transfer payments? The basic message is that in judging the durability of a fiscal adjustment and its effects, the devil is in the details.

The present paper combines two strands of the literature on fiscal adjustment. First, it builds on the pioneering work on expansionary fiscal consolidation initiated by Francesco Giavazzi and Marco Pagano in 1990. These authors look closely at the 1987-89 Irish stabilization and the 1983-86 Danish stabilization and find that those adjustments seemed to have had expansionary rather than contractionary effects. ${ }^{1}$

The other strand of literature is the work by Alesina and Perotti themselves, beginning with their 1995 paper relating the success of fiscal consolidation to its detailed composition. ${ }^{2}$ I should warn at the outset-as the authors have done explicitly-that in this paper and its predecessors they use a short-term definition of success, which revisits the fiscal scene only once, rather shortly after a stabilization, to check for durability. One sees a success in the data followed by another five years later, and one is left wondering how successful the first "success" really could have been.

1. Giavazzi and Pagano (1990).

2. Alesina and Perotti (1995). 
Keeping in mind this caveat, however, Alesina, Perotti, and their collaborators have suggested some striking results. Reductions in the government wage bill and in transfer payments seem to guarantee relatively durable fiscal consolidation, whereas tax hikes and cuts in government investment apparently are reversed more quickly. They conjecture that durability is related to the greater political difficulty in achieving cuts in government wage spending and transfers compared with, say, letting infrastructure deteriorate for a while. The former type of budgetary change requires a degree of political courage or consensus that appears to be associated with longer lasting fiscal restraint. In further work, these authors have examined the economic effects of fiscal shifts. Their headline finding is that durable fiscal adjustments do not seem to dampen economic growth, whereas adjustments based primarily on higher taxes or public investment cuts do.

In their 1995 paper Alesina and Perotti raised, but did not address, the question of whether governments are punished for cutting government wages or transfer payments. The main contribution of the present paper is to take up this issue. The answer that comes out of the analysis is no. The authors propose that voters may really be fiscal conservatives. A government need only bite the bullet to get its fiscal house in order; it will not be punished, growth will not suffer, and the economy will be on a better footing thereafter. From the politician's perspective, the gain comes with little or no pain.

The view that the composition of fiscal adjustment matters for sustainability has already been quite influential. The European Commission's Convergence Report, which, only two days before this paper was presented, nominated the initial entrants to European economic and monetary union, states:

There is ample evidence that both the size and composition of budgetary adjustments are important in determining whether they will be successful in having a durable impact on the government's position and thus in shifting the government debt ratio onto a declining path. Large and persistent adjustment efforts tend to be more successful, and deficit reductions which take place through cuts in current primary expenditure rather than tax increases are less likely to be reversed in the future. Budgetary adjustments strongly based on cuts in current primary expenditure are often more difficult to implement and their adoption is therefore 
a clear sign of the government's commitment to budgetary discipline and of its determination to maintain these efforts in the future. ${ }^{3}$

While there is some consensus on the factors that might promote a degree of durability, the national political ramifications of alternative strategies for budgetary adjustment have not been systematically explored until the current paper. Plainly, these too could be critical to the performance of EMU.

The first part of the paper deals with the contrast between contractionary and expansionary fiscal adjustments, reviewing several models and mechanisms. Early literature in this area concentrated on the private consumption response to different types of fiscal shifts. When one looks at the data for a large sample of OECD stabilizations, as Alesina and Perotti have done elsewhere and as this paper does in table 4, other regularities stand out. ${ }^{4}$ Most important, much of the action takes place in investment rather than in consumption. In addition, successful fiscal adjustments seem to coincide with rises in the share of profits in income.

Unit labor costs fall during adjustments. The authors hypothesize that when a government cuts its wage bill, there is a reduction in the demand for labor, which, in a heavily unionized labor market, leads quickly to a lower unit labor cost. One could point to additional mechanisms that work in this direction. For example, lower transfer payments could intensify job search efforts by the unemployed, also lowering the bargaining power of employed workers.

Other regularities are evident in the data, however, suggesting an alternative view of successful adjustments: perhaps successful fiscal adjustments occur after the economy has deteriorated to the point where there is political support for the government to make tough choices and make the consolidation stick. In this case, the pain of the adjustments and the permanence of the fiscal improvement are driven by a common factor: a preexisting state of crisis (or at least, malaise).

While unit labor costs fall during successful adjustment years, a striking regularity in table 4 is that they fall even more rapidly immediately before those adjustment years, and they rise rather dramatically

3. European Commission (1998, p. 105). This report was issued on March 25, 1998.

4. See Alesina and Perotti (1997a, table 10, p. 226). 
just afterward. ${ }^{5}$ The reason for the large pre-adjustment unit labor cost decline may well be that money wages are sticky and the exchange rate is falling more sharply before successful adjustments than it is before unsuccessful ones. Rather than the labor market adjustments the authors stress, an overshooting currency depreciation that is subsequently reversed may explain much of the dynamic pattern that unit labor costs follow. Moreover, both before and throughout the adjustment process, countries that consolidate durably tend to have higher shares of wages in GDP and lower shares of profits. As a result of the successful adjustments, these relatively high wage shares decline somewhat, and the profit shares rise.

One therefore has the following picture of the economy before a successful adjustment. Productivity-adjusted nominal wages are unusually high, compared with those of trading partners. The economy is uncompetitive. Investment is low, in part because the profit share is depressed. The wage share is correspondingly high, and the currency is in a tailspin. Overall, the economy is in crisis and there is public support for a stern consolidation. Certainly, the Irish and Danish stabilizations studied by Giavazzi and Pagano fit this mold.

As the authors recognize, the full story of how an adjustment takes place, why it is successful, and why it (perhaps) has the voters' support, requires consideration of the total policy package deployed and the preexisting economic and political situation from which those measures arise. Their basic finding about political change following an adjustment is that there is no evidence of political retribution for fiscal adjustments. Indeed, there is some evidence that tougher adjustmentsthat is, on wages and transfers-may be rewarded.

A striking by-product of the econometrics is that growth rates of unemployment and output do not seem to affect electoral outcomes. As the authors point out, this is not the case in U.S. data. The discrepancy raises a puzzle for future research. Are the more extensive social safety nets in European countries responsible for voter complacency? Are effects masked by the dominant structural component of European unemployment? The variable that does matter is inflation. This fact reinforces my suspicion that rapid currency depreciation supports determined fiscal stabilization by causing widespread public alarm.

5. This pattern differs from the one reported in Alesina and Perotti (1997a, table 10) over a slightly different sample of adjustment episodes. 
The authors define a change in government or a change in the ideology of a cabinet in various ways. As they admit, however, it is hard to handle the variety of electoral events that could be significant. For example, the outcome of the 1994 U.S. congressional elections in part reflected voters' revenge for earlier tax hikes. Since that election did not change the executive, though, it would not appear in the authors' sample of political changes. In a related vein, how would one handle by-elections that reduce the government's majority, or local elections that send signals of voter discontent? The authors draw on popularity polls to address this point, but the reliability of these polls may be suspect. Former president George Bush's self-reassuring observation that "the only poll that matters is the one on Election Day" contains a grain of truth.

A general concern in detecting fiscal events is the possibility of big fiscal changes that do not have short-run effects on the budget. For example, changing an entitlement program or the inflation indexation of benefits might only affect deficits after some time and might not produce any noticeable short-run effect on transfer payments, but voters' anger could be aroused immediately. A related point is that the deficit numbers may misstate the true intergenerational redistribution effects of policies. It would be interesting to perform this paper's exercise from a generational accounting perspective.

I also worry about the counterfactual in thinking about the political response to fiscal changes. An important finding of this paper is that governments are not rewarded for deficits. But perhaps they would have been punished for not raising spending or for not instituting certain support programs. The question of causality is central to drawing policy implications from the empirical results on political sequelae. If successful adjustments largely occur in crisis situations, and voters favor resolution of the crisis, the government will not be punished if its efforts at consolidation succeed. But the crisis has to be there first and is itself related to earlier policies.

The authors suggest that voters might be fiscal conservatives. I find this much more plausible at the local than at the national level. At the national level, there are too many "others" onto whom the burden of public spending can be shifted. The French have shown at the polls that they surely are not fiscal conservatives in this sense, no matter who else is. 
I also suspect the authors are too sanguine about how straightforward it is to rectify a fiscal imbalance. It may be that biting the bullet works, but only after a country has entered a crisis severe enough to command public support for general sacrifice. Looking at the recent experience in Europe, one would think that the Maastricht macroeconomic convergence process would have provided a great opportunity for governments to bite the bullet and make truly fundamental fiscal reforms. And if European voters are fiscal conservatives at heart, this should have been all the more easy. But one does not see this from the data on the composition of recent fiscal adjustments, notwithstanding the European Commission's protestations to the contrary. There are some cuts in government wages and transfers, but most of the adjustments-leaving aside the countries that had escaped "excessive deficit" status prior to 1998-have come through revenue increases, delayed infrastructure maintenance, lower interest on public debt due to expected interest rate convergence, and the like. ${ }^{6}$

To sum up, I view this as a stimulating and important line of work. I look forward to more of it, and especially to more case studies, which might prove to be a better calibrated instrument for understanding the political ramifications of fiscal cuts. The paper's implications for the design of fiscal policies are important. One clear application is to the EMU stability pact, which seeks to limit fiscal deficits in member states to 3 percent of GDP through the threat of sanctions. The stability pact does not deal with the roots of fiscal problems, but rather with their symptoms, and its focus on the deficit as a measure of fiscal pressure is too blunt. True, the worst fiscal excesses of the past in Europe will not reappear soon. But the current design of fiscal coordination in EMU does little to prevent government deficits from approaching the statutory reference maximum too often for comfort. Thus the stability pact sets the stage for potentially serious political divisions among member states. From that perspective, the author's findings should be especially sobering for Europeans. If politicians buy the message that serious fiscal reform comes without political cost, act accordingly, and indeed come up winners, excessive deficit situations will be infrequent. But for the big players in EMU, in the near term, that scenario seems overoptimistic.

6. See Obstfeld (1997). 
Barry Eichengreen: This is a fitting paper to mark the Brookings Panel's celebration of the elimination of the U.S. budget deficit. There have been not a few Brookings Papers analyzing the effects of budget deficits on the U.S. economy. ${ }^{1}$ Now the deficit is finally a thing of the past, and discussion has turned to the best way to utilize the surplus. Controversy remains about the extent to which the economic initiatives taken by the first Clinton administration and the 103d Congress have contributed to closing the fiscal gap, as against the unusually persistent economic expansion that has dominated the 1990s-and which may have occurred for largely independent reasons, including some emanating from a building four blocks due west of the White House. According to the administration's estimates, only $\$ 103$ billion of the $\$ 280$ billion decline in the budget deficit between 1992 and 1998 is due to improvement in the economy, while the rest is due to fiscal policy changes. ${ }^{2}$ The question is whether those supposedly autonomous changes - welfare reform, for example - really are independent of the cycle, or they will be rolled back when the next recession hits, and the states will again appear on the federal doorstep, pleading for help with their welfare programs. The debate will continue, more intensely as the electoral season approaches. Alesina, Perotti, and Tavares perform a service by reminding one that the variability in cross-country data can be quite useful for answering such questions.

This is also an appropriate paper with which to celebrate these authors' previous contributions to the literature on fiscal policy. It is standard nowadays to distinguish fiscal contractions from fiscal consolidations and to give credence to the idea that reductions in budget deficits can be expansionary under certain circumstances. For this insight one has the authors and their collaborators to thank.

Their point is that reductions in budget deficits can be expansionary, even in the short run, if those reductions are large, enduring, and take the form of spending cuts on transfer payments and public sector salaries, in particular. This type of deficit reduction can have a large positive effect on consumer confidence and investment spending. Denmark and Ireland in the 1980s have been identified as examples, and subse-

1. Economic historians will remember Teeters (1972); Perry (1975); Friedman (1978); Hubbard and Judd (1986).

2. Budget of the United States Government, Analytical Perspectives, Fiscal Year 1999, table 1-5, p. 12. 
quent work, extended and consolidated here, suggests that this result carries over to a larger sample of countries.

The obvious objection is on grounds of simultaneity bias. By the authors' argument, deficit reductions-or more precisely, certain kinds of deficit reductions-raise the rate of economic growth. But one also knows that faster growth favorably affects the deficit. A common academic game is to take a supposed instance of expansionary fiscal contraction and argue that the economy was in fact stimulated by some omitted variable that raised output and induced the observed fall in the budget deficit. For Denmark and Ireland in the 1980s, for example, analysts argue that fiscal consolidation occurred during the period of the soaring U.S. dollar; the favorable competitiveness effects of these countries' depreciating real exchange rates therefore swamped the negative output effects of the contractionary fiscal impulse. The authors are aware of this problem, and they attempt to it solve by cyclically adjusting the deficit. But the one thing economists know about cyclical adjustments is that we do not know how to do them: we do not know whether business cycles are symmetric, we do not know whether they are alike, we do not know the size of the unit-root component.

Note, also, that while the authors correct the deficit (as well as total primary expenditures and total revenues) for the cycle, table 3 comparing changes in the composition of expenditure between sustained and transitory (that is, "successful" and "unsuccessful") fiscal adjustments relies on cyclically uncorrected figures. During a sustained adjustment, according to this table, a good deal of the spending reduction comes out of transfers. But this is the subcategory of public spending that is likely to be particularly sensitive to the cycle. An alternative interpretation, therefore, is that when there is a sustained acceleration in growth for reasons having little to do with fiscal policy, much of the induced reduction in the deficit takes the form of a fall in government transfers. Convincing skeptical readers will thus require sensitivity analysis using alternative cyclical corrections and correcting for the cycle not only total expenditure, but also its components.

Indeed, there are economic as well as statistical reasons to question whether the balance of tax increases and spending cuts, and the composition of the latter, are in fact the dominant determinants of a deficit reduction being expansionary or contractionary. An alternative hypothesis is that the macroeconomic effects hinge on initial conditions. The 
effect of fiscal consolidation on consumer confidence and consumer spending is likely to resemble the effect of speed on passengers' peace of mind in a moving car. If the car is hurtling toward a brick wall, stepping on the brakes will increase the confidence of the passengers. Likewise, if fiscal policy is on an unsustainable trajectory, with explosive growth in the ratio of debt to GNP, stepping on the budgetary brakes will increase confidence, encourage consumer spending, and stimulate investment, because households and firms believe that adjustment today will obviate the need for more painful and costly adjustment tomorrow. But if the car is creeping along an empty highway, the passengers will begin to wonder whether they are ever going to reach their destination; if the driver steps on the brakes, the passengers will throw up their hands in despair. And when there is no problem of fiscal sustainability, spending cuts or tax increases are more likely to elicit the standard textbook response.

Thus by focusing on large budget cuts, persistent budget cuts, and budget cuts dominated by transfers and the public sector wage bill, the authors overlook the principal determinant of whether those cuts are expansionary or contractionary, namely, the initial conditions, and in particular, whether fiscal policy is on a sustainable course or not. One would expect budget cuts of the same size, persistence, and composition to have very different effects, depending on the initial debt-to-GNP ratio, the growth rate of the economy, and the real interest rate. I have already mentioned why the evidence from Ireland and Denmark in the 1980s is difficult to interpret, but for those who believe that these fiscal consolidations were expansionary, it is precisely the fact that the ratio of debt to GDP was exploding in these countries that lends credence to the argument.

Figure B1 puts together the points discussed above, where the horizontal axis represents GNP and the vertical axis represesents the deficit. The downward-sloping curve is the response of the deficit to GNP; I label it the revenue effect (although there may also be some induced reduction in deficit spending with growth, due to lower outlays on, inter alia, unemployment compensation). The other curve, which slopes up but bends back when deficits reach sufficiently high levels, represents the direct effect of deficit spending on GNP. I label this the multiplier effect, with the understanding that the multiplier can be positive or negative. One thus has a "Keynesian" range of small deficits and 
Figure B-1. Interaction between Fiscal Policy and Output

Deficit

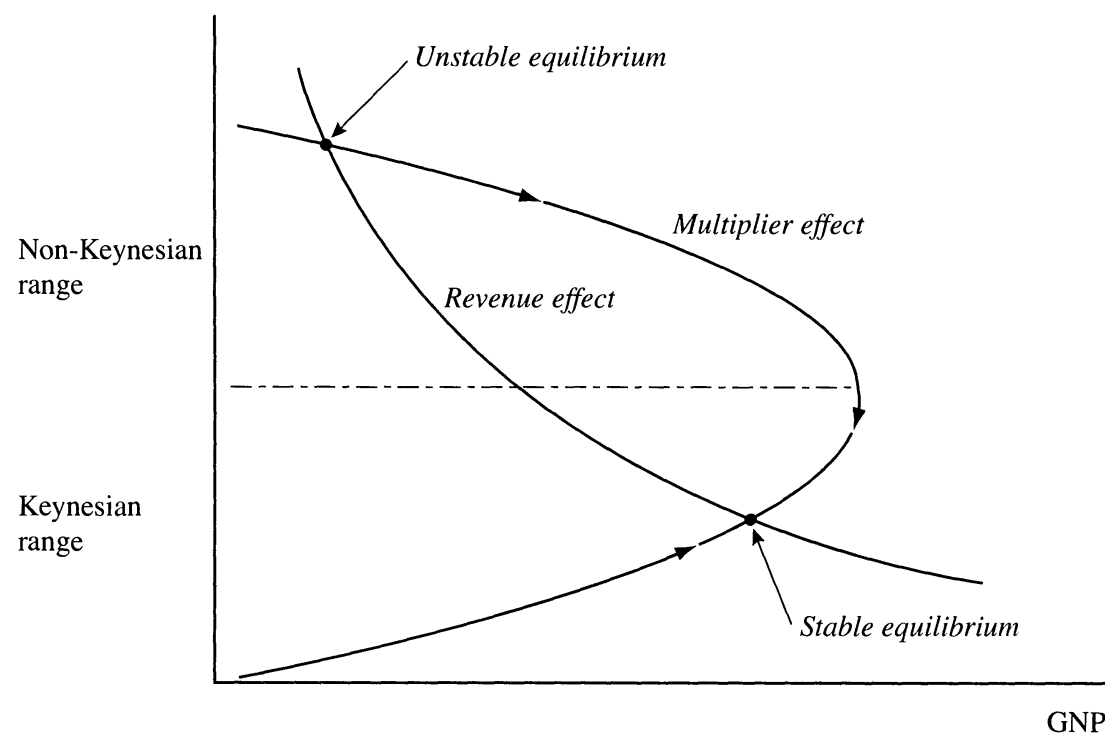

"non-Keynesian" range of large deficits. There are two equilibria, and only the low-deficit equilibrium is stable. If revenues respond to output with a lag and the economy is always on the multiplier curve, then a small perturbation in the neighborhood of the low-deficit equilibrium will have only a small output effect; but an equally small perturbation in the neighborhood of the high-deficit equilibrium can have a very large output effect. Accordingly, it is not just the composition, size, or persistence of the deficit cut that matters, but the initial conditions.

There is reason to think that initial conditions also determine whether deficit reductions through spending cuts have more favorable output effects than do deficit reductions through tax increases. To be sure, in Northern Europe, where the initial condition is a bloated public sector, a fiscal consolidation that emphasizes spending cuts is very likely to have favorable output effects. But in Russia, to take an extreme counterexample, the initial condition is deficits due to tax avoidance and unsatisfactory revenue performance generally. In this case, fiscal consolidation through greater tax effort is likely to be more sustainable 
than attempting further cuts in the social safety net. Most countries lie between these extremes, but precisely where is not clear.

Note that table 5, in which the authors analyze the correlation between successful and unsuccessful adjustments and initial conditions (in the form of the level of and accumulated change in the public debt ratio), is consistent with this emphasis. This table shows that governments are more likely to implement sustained fiscal consolidations when initial conditions are poor. Since the authors show elsewhere in the paper that successful adjustments are more likely to be expansionary, one can infer that fiscal adjustments undertaken when initial conditions are poor have the most positive macroeconomic effects, although this point is not analyzed explicitly. Nor do the authors take the critical final step of asking whether the mix of tax increases and spending cuts, and the composition of the latter, still significantly shape the macroeconomic response after controlling for those initial conditions.

The authors' new results on the political consequences of fiscal adjustments are especially interesting. They find that looser fiscal policies do not increase a government's chances of political survival, and that cuts in the public sector wage bill and in transfer payments do not increase the chances of government collapse. This poses a paradox: if fiscal consolidation is rewarded, or at least if governments are not penalized for it, why then are they so reluctant to undertake it? The authors suggest that transfer recipients and public employees, spending on whom must be cut if the fiscal consolidation is to be sustainable, comprise a formidable blocking coalition.

The zero coefficient on the deficit on which this conclusion hinges is an example of the Frankel recipe for success: "The secret of empirical work is to define your hypothesis so that failure to find significant results can be interpreted as support." ${ }_{3}$ In particular, I worry that this zero coefficient is a product of multicolinearity. According to the authors' own arguments, minority coalition governments will find it difficult to engineer sustained reductions in deficit spending, because they are unable to form the kind of encompassing coalitions needed to achieve agreement on sacrifices all around. But one also knows, from the electoral politics literature, that political fragmentation-good proxies for which are coalition status, the number of parties in the coalition, and 
majority or minority status in the parliament-is the most robust predictor of government tenure. These variables affect cabinet changes directly but also affect the change in the deficit, so that the effect of the latter on cabinet changes is likely to be difficult to pin down.

Hence I am more impressed by the regressions in which the authors attempt to distinguish the effects of large deficit cuts and of fiscal consolidations that mainly take the form of spending cuts on political popularity and government survival. Again, however, the troubling fact is that most of the relevant coefficients are insignificantly different from zero. In any case, if one believes that rather than the magnitude or the composition of the change in the deficit, it is initial conditions that are important, it is not entirely clear what to make of these results.

Reverse causality is an issue here as well, and the authors go to considerable lengths to address it. They look at the timing of changes in government and fiscal policy, experiment with instruments, and focus on a subset of exogenously imposed changes in fiscal stance associated with the requirements of the Maastricht treaty, asking whether the response to these is any different. Let me comment on the last. Assume that fiscal consolidation really does reduce government popularity, but ordinary least squares regressions fail to pick this up because unusually popular governments use their surplus political capital to reduce deficits. Because Maastricht-mandated reductions are exogenous (ignoring Pogo's problem, "I have met the signatories of the Maastricht treaty, and they are us"), reverse causality is less of a problem, and one should expect a negative effect of deficit reduction. But a Maastricht-mandated deficit reduction yields not only a different fiscal position but also the reward of qualifying for monetary union, which one presumes would have a positive effect on popular support for the government, especially in countries like Italy, where deficit reduction is a pressing issue. Given this unique payoff structure, it is not surprising that the authors again fail to find a negative impact of deficit cuts on government popularity.

General discussion: Alan Blinder thought that the paper did not pay sufficient attention to the endogenous response of monetary policy to fiscal contractions that may partially offset their effect. Robert Gordon and James Duesenberry agreed with Blinder, arguing that it was important to take into account the entire policy package, which might be designed to offset fiscal contraction with expansionary monetary policy 
or devaluation. For example, Gordon suspected that in the case of countries that left the European Exchange Rate Mechanism in 1992, the contractionary effect of fiscal retrenchment may have been at least partly offset by the expansionary effects of devaluations. He also suggested that governments tend to pursue fiscal consolidation during times of robust GDP growth and thought that the paper did not pay sufficient attention to the possibility that initial conditions were driving their results.

In the same vein, David Laibson remarked that the average popularity of governments that engaged in fiscal adjustments did not convey enough information about the circumstances under which governments carried out reform. Popularity may give a government the opportunity to make a difficult adjustment, but governments in crisis, with low popularity, may also find the pressure for reform to be great. He suggested that it would be interesting to see the full distribution of popularity for governments that undertook reform. Laibson also pointed out that it may be difficult to generalize the authors' conclusions from reactions to adjustments imposed by the Maastricht criteria to adjustments under circumstances in which a government acted at its own will.

Richard Cooper was skeptical of the authors' results. He noted that in France and Germany, despite long ongoing debates, governments had not succeeded in controlling their expenditures. Either politicians did not understand the business they were in-a conclusion at odds with the usual omniscience and rationality postulates in modern economic theory - or there were important factors present in the real world that the authors had omitted. Blinder queried the authors' view that politicians find it easier to raise taxes than to reduce government spending. He did not believe this true for "Anglo" countries. Frank Stafford suggested that fiscal adjustments were more likely to receive popular support when they were associated with reforms of transfer systems that are perceived as unfair.

Christopher Sims suggested that the right conclusion to draw from the authors' results is that it is hard to tell from these data whether or not deficits matter to political outcomes. There is a strong negative simple correlation of deficit changes with changes in government, and a positive simple correlation between changes in deficit and popularity. Not surprisingly, when lots of other cyclical variables are included in the authors' regression framework, almost everything appears insignif- 
icant. There is just not enough independent variation among the variables to sort out their individual importance.

Benjamin Friedman expressed concern about the short horizon used in the definition of "successful" adjustments, on the ground that some adjustments may at first appear to be successful, only to unravel after just a few years. He also suggested investigating whether the political ramifications of successful consolidations were different from those of unsuccessful ones. 


\section{References}

Alesina, Alberto, and Silvia Ardagna. 1998. "Tales of Fiscal Adjustments." Economic Policy (forthcoming).

Alesina, Alberto, and Allan Drazen. 1991. "Why are Stabilizations Delayed?" American Economic Review 81(5): 1170-88.

Alesina, Alberto, and Roberto Perotti. 1995. "Fiscal Expansions and Adjustments in OECD Countries." Economic Policy 21: 205-48

3(1): 113-34.

$\rightarrow$. 1997a. "Fiscal Adjustments in OECD Countries: Composition and Macroeconomic Effects." International Monetary Fund Staff Papers 44(2): 210-48.

1997b. "The Welfare State and Competitiveness." American Economic Review 87(5): 921-39.

Alesina, Alberto, Alessandro Prati, and Guido Tabellini. 1990. "Public Confidence and Debt Management: A Model and a Case Study of Italy." In Public Debt Management: Theory and History, edited by Rudiger Dornbusch and Mario Draghi. Cambridge University Press.

Alesina, Alberto, and Howard Rosenthal. 1995. Partisan Politics, Divided Government, and the Economy. Cambridge University Press.

Alesina, Alberto, Nouriel Roubini, and Gerald D. Cohen. 1997. Political Cycles and the Macroeconomy. MIT Press.

Alesina, Alberto, and others. 1992. "Default Risk on Government Debt in OECD Countries.' Economic Policy 15: 427-63.

Banks, Arthur S., and others, eds. 1996. Political Handbook of the World: 1995-1996. Binghampton, N.Y.: CSA Publications.

Baxter, Marianne, and Robert G. King. 1993. "Fiscal Policy in General Equilibrium." American Economic Review 83(3): 315-34.

Bertola, Giuseppe, and Allan Drazen. 1993. "Trigger Points and Budget Cuts: Explaining the Effects of Fiscal Austerity." American Economic Review 83(1): 11-26.

Blanchard, Olivier Jean. 1990a. "Comment." In NBER Macroeconomics Annual 1990, edited by Olivier Jean Blanchard and Stanley Fischer. MIT Press.

_ 1990b. "Suggestions for a New Set of Fiscal Indicators." Working Paper 79. Paris: Organisation for Economic Co-operation and Development (April).

Budge, Ian, Hans Keman, and Jaap Woldendorp. 1993. "Political Data 194590." European Journal of Political Research 24(1): 1-120.

Calvo, Guillermo A. 1988. "Servicing the Public Debt: The Role of Expectations." American Economic Review 78(4): 647-61. 
Cukierman, Alex, and Mariano Tommasi. 1998. "When Does It Take a Nixon to Go to China?' American Economic Review 88(1): 180-97.

European Commission. 1998. Convergence Report 1998. Brussels.

Fair, Ray C. 1978. "The Effect of Economic Events on Votes for President.", Review of Economics and Statistics 60(2): 159-73.

Friedman, Benjamin M. 1978. "Crowding Out or Crowding In? Economic Consequences of Financing Government Deficits.' BPEA, 3:1978, 593654.

Gavin, Michael, and Roberto Perotti. 1997. "Fiscal Policy in Latin America.', In NBER Macroeconomics Annual 1997, edited by Ben S. Bernanke and Julio Rotemberg. MIT Press.

Giavazzi, Francesco, and Marco Pagano. 1990. “Can Severe Fiscal Adjustment Be Expansionary? Tales of Two Small European Countries.' In NBER Macroeconomics Annual 1990, edited by Olivier Jean Blanchard and Stanley Fischer. MIT Press.

. 1996. "Non-Keynesian Effects of Fiscal Policy Changes: International Evidence and the Swedish Experience.' Swedish Economic Policy Review 3(1): 67-103.

Grilli, Vittorio, Donato Masciandaro, and Guido Tabellini. 1991. "Political and Monetary Institutions and Public Financial Policies in the Industrial Countries." Economic Policy 6: 341-92.

Hallerberg, Mark, and Jürgen von Hagen. 1997. 'Electoral Institutions, Cabinet Negotiations, and the Budget Deficits within the European Union." Discussion Paper 1555. London: Centre for Economic Policy Research.

Hubbard, R. Glenn, and Kenneth L. Judd. 1986. “'Liquidity Constraints, Fiscal Policy, and Consumption.' BPEA, 1:1986, 1-60.

International Monetary Fund. 1996. World Economic Outlook. Washington.

Kontopoulos, Yanos, and Roberto Perotti. 1997. "Fragmented Fiscal Policy., Unpublished paper. Columbia University.

Kraemer, Moritz. 1997. "Electoral Budget Cycles in Latin America and the Caribbean: Incidence, Causes, and Political Futility.' Working Paper 354. Washington: Inter-American Development Bank.

Kramer, Gerald H. 1971. " Short-Term Fluctuations in U.S. Voting Behavior, 1896-64.' American Political Science Review 65(1): 131-43.

Krugman, Paul. 1996. “Are Currency Crises Self-Fulfilling?', In NBER Macroeconomics Annual 1996, edited by Ben S. Bernanke and Julio J. Rotemberg. MIT Press.

Lewis-Beck, Michael S. 1988. Elections and the Economy. Oxford University Press.

Lowry, Robert, James Alt, and Karen Ferre. 1997. “Fiscal Policy Outcomes and Electoral Accountability.' Unpublished paper. Harvard University.

$\rightarrow$ McDermott, C. John, and Robert F. Wescott. 1996. “An Empirical Analysis 
of Fiscal Adjustments." International Monetary Fund Staff Papers 43(4): 725-53.

Miller, Marcus H., Robert Skidelsky, and Paul Weller. 1990. "Fear of Deficit Financing-Is It Rational?' In Public Debt Management: Theory and History, edited by Rudiger Dornbusch and Mario Draghi. Cambridge University Press.

Nordhaus, William D. 1975. "The Political Business Cycle." Review of Economic Studies 42(2): 169-90.

Obstfeld, Maurice. 1997. “Europe's Gamble." BPEA, 2:1997, 241-317.

Paldam, Martin. 1991. "How Robust Is the Vote Function? A Study of Seventeen Nations over Four Decades." In Economics and Politics: The Calculus of Support, edited by Helmut Norpoth, Michael S. Lewis-Beck, and Jean-Dominique Lafay. University of Michigan Press.

Peltzman, Sam. 1992. "Voters as Fiscal Conservatives." Quarterly Journal of Economics 107(2): 327-61.

Pencavel, John H. 1986. "Labor Supply of Men: A Survey." In Handbook of Labor Economics, vol. 1, edited by Orley Ashenfelter and Richard Layard. Amsterdam: North Holland.

Perotti, Roberto. 1997. "Fiscal Policy When Things Are Going Badly." Unpublished paper. Columbia University (October).

Perry, George L. 1975. "Policy Alternatives for 1974."' BPEA, 1:1975, 22235.

Persson, Torsten, and Lars E. O. Svensson. 1989. "Why a Stubborn Conservative Would Run a Deficit: Policy with Time-Inconsistent Preferences." Quarterly Journal of Economics 104(2): 325-45.

Powell, G. Bingham Jr., and Guy D. Whitten. 1993. "A Cross-National Analysis of Economic Voting: Taking Account of the Political Context." American Journal of Political Science 37(2): 391-414.

Rogoff, Kenneth. 1990. "Equilibrium Political Budget Cycles." American Economic Review 80(1): 21-36.

Shiller, Robert J. 1996. “Why Do People Dislike Inflation?” Working Paper 5539. Cambridge, Mass.: National Bureau of Economic Research (April).

Spolaore, Enrico. 1993. "Policy-Making Systems and Economic Efficiency: Coalition Governments vs. Majority Governments." Unpublished paper. Harvard University.

Strom, Kaare, and Martin Lipset. 1984. "Macroeconomics and Macropolitics: The Electoral Performance of Democratic Government." Unpublished paper.

Summers, Lawrence H., and Olivier Jean Blanchard. 1990. "Hysteresis and the European Unemployment Problem.' In Understanding Unemployment, edited by Lawrence H. Summers. MIT Press.

Sutherland, Alan. 1997. "Fiscal Crises and Aggregate Demand: Can High 
Public Debt Reverse the Effects of Fiscal Policy?', Journal of Public Economics 65(2): 147-62.

Tabellini, Guido, and Alberto Alesina. 1990. "Voting on the Budget Deficit." American Economic Review 80(1): 37-49.

Tavares, José. 1998. "Does Right or Left Matter? Cabinets, Credibility and Fiscal Adjustments." Unpublished paper. Harvard University (May).

Teeters, Nancy H. 1972. “'Outlook for Federal Fiscal Policy.” BPEA, 2:1972, 467-77.

Velasco, Andrés. 1996. “A Model of Fiscal Deficits and Delayed Fiscal Reforms." Unpublished paper. New York University. 